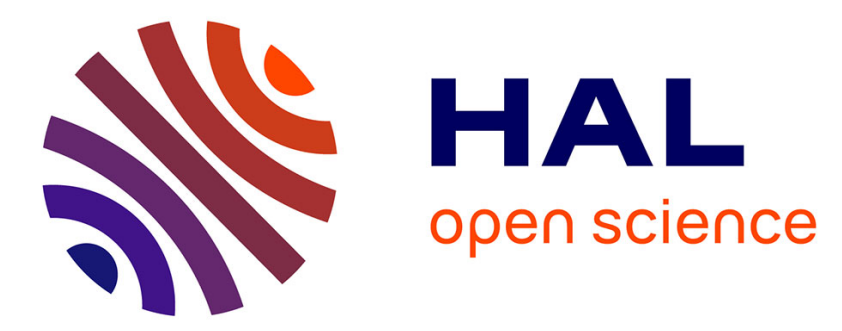

\title{
Cretaceous exhumation of the Triassic intracontinental Xuefengshan Belt: Delayed unroofing of an orogenic plateau across the South China Block?
}

\author{
Yang Chu, Wei Lin, Michel Faure, Mark Allen, Zhentian Feng
}

\section{To cite this version:}

Yang Chu, Wei Lin, Michel Faure, Mark Allen, Zhentian Feng. Cretaceous exhumation of the Triassic intracontinental Xuefengshan Belt: Delayed unroofing of an orogenic plateau across the South China Block?. Tectonophysics, 2020, 793, pp.228592. 10.1016/j.tecto.2020.228592 . insu-02923374

HAL Id: insu-02923374

https://hal-insu.archives-ouvertes.fr/insu-02923374

Submitted on 27 Aug 2020

HAL is a multi-disciplinary open access archive for the deposit and dissemination of scientific research documents, whether they are published or not. The documents may come from teaching and research institutions in France or abroad, or from public or private research centers.
L'archive ouverte pluridisciplinaire HAL, est destinée au dépôt et à la diffusion de documents scientifiques de niveau recherche, publiés ou non, émanant des établissements d'enseignement et de recherche français ou étrangers, des laboratoires publics ou privés. 


\section{Journal Pre-proof}

TEGTONOPHYSICS

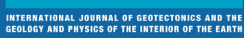

Cretaceous exhumation of the Triassic intracontinental Xuefengshan Belt: Delayed unroofing of an orogenic plateau across the South China Block?

Yang Chu, Wei Lin, Michel Faure, Mark B. Allen, Zhentian Feng

PII: $\quad$ S0040-1951(20)30275-4

DOI: $\quad$ https://doi.org/10.1016/j.tecto.2020.228592

Reference: $\quad$ TECTO 228592

To appear in: $\quad$ Tectonophysics

Received date: $\quad 22$ May 2020

Revised date: $\quad 8$ August 2020

Accepted date: $\quad 11$ August 2020

Please cite this article as: Y. Chu, W. Lin, M. Faure, et al., Cretaceous exhumation of the Triassic intracontinental Xuefengshan Belt: Delayed unroofing of an orogenic plateau across the South China Block?, Tectonophysics (2020), https://doi.org/10.1016/ j.tecto.2020.228592

This is a PDF file of an article that has undergone enhancements after acceptance, such as the addition of a cover page and metadata, and formatting for readability, but it is not yet the definitive version of record. This version will undergo additional copyediting, typesetting and review before it is published in its final form, but we are providing this version to give early visibility of the article. Please note that, during the production process, errors may be discovered which could affect the content, and all legal disclaimers that apply to the journal pertain.

C 2020 Published by Elsevier. 


\section{Cretaceous exhumation of the Triassic intracontinental Xuefengshan Belt: delayed unroofing of an orogenic plateau across the South China Block?}

Yang Chu ${ }^{1,2,3,}{ }^{*}$, Wei Lin ${ }^{1,2}$, Michel Faure ${ }^{4}$, Mark B. Allen ${ }^{3}$, Zhentian Feng $^{1,2}$

1. State Key Laboratory of Lithospheric Evolutio. I, In titute of Geology and Geophysics, Institutions of Earth Sciences, C, rose Academy of Sciences, Beijing 100029, China

2. University of Chinese Academ, of Sciences, Beijing 100049, China

3. Department of Earth Sciences, In versity of Durham, Durham DH1 3LE, UK 4. Institut des Sciences de ^. Terre d'Orléans, UMR 7327, Université d'Orléans, Orléans 45071, Frans .

*Corresponding author. Yang Chu (chuyang@mail.iggcas.ac.cn), Institute of Geology and Geophysics, Chinese Academy of Sciences, 19 Beitucheng western Road, Chaoyang District, 100029 Beijing, P. R. China 


\section{Abstract:}

A large plateau can be produced by crustal thickening in convergent zones such as continental collision belts and Andean-type subduction zones, but the life cycles of such plateaux are not well-understood. In particular, it is not clear how long they persist after construction, before other tectonic processes or erosion reduce crustal thickness and elevation to near-normal levels. Triassic subduction- and collision-tectonics produced intense deformation, magmat and metamorphism across the entire South China Block. This large-scale c 'ust: 1 shortening created a broad orogenic belt, uplifted most parts of the Sol th China Block, and probably initiated the growth of an orogenic plateau. $\mathrm{C}, \mathrm{u}^{\prime}$ study presents low-temperature thermochronology data from the Xuef $\mathrm{en}_{\xi}$ sha: Belt in the interior of the South China Block. There was along-strike vai 'tion in exhumation. The north orogenic core was subjected to Triassic ( 245-210 $\mathrm{V}$ $\mathrm{q})$, and Late Cretaceous ( 100-80 Ma) exhumation, whereas the cooling path oi the south orogenic core reflects a two stage Cretaceous evolution. The variab'. 'xirumation pattern reflects non-uniform tectonics in different regions, but both regı ns were subject to Late Cretaceous extension. We tentatively reconstruct the original plateau paleo-elevation to be $\sim 1.5 \mathrm{~km}$ above sea level, based on the amount of exhumation $(\sim 10 \mathrm{~km})$ and the present crustal thickness $(\sim 35 \mathrm{~km})$. The T-t trajectories of the Xuefengshan Belt and other Triassic belts highlight the significance of Cretaceous extension and exhumation in shaping the tectonic configuration of the South China Block. Large-scale extension was probably triggered by rollback of the Paleo-Pacific subduction zone. 
Key words: Cretaceous extension; delayed exhumation; thermochronology;

Mesozoic plateau; Xuefengshan; South China

\section{Introduction}

This paper presents new thermochronology data for the Xuefengshan Belt (XFSB) of the South China Block (SCB), to explore its ex'.u nation history and how and when Triassic metamorphic belts were modified ir to th eir present configurations. We use the results and regional context to propos : tha ${ }^{+}$a large part of the SCB was an orogenic plateau for much of the Mesozoic, $v 11$ similarities to modern examples of the Central Andes, Iranian and Tibeta $1 \mathrm{p}$ atea $\mathrm{dx}$. The wider aim is to shed light on the

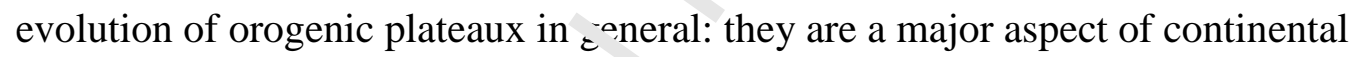
tectonics and growth, but their life cy cles are not well-understood. Although the part of the adjacent North Chin $\mathfrak{a}$ Block has previously been interpreted as an orogenic plateau in the Mesozrin 'e.s. Zhang et al., 2008), we are not aware that the SCB has been viewed in this w, y before.

The XFSB is part of a large Triassic intracontinental fold-and-thrust belt within the southeast and center of the SCB (Fig. 1). Ductile deformation of pre-Late Triassic rocks in the XFSB progressed from the southeastern margin towards the interior of the continent (Li ZX and Li XH, 2007; Chu et al., 2012a; Shu et al., 2015), in response to Paleo-Pacific subduction beneath this margin. Deformation affected other areas of the SCB in the Triassic as the result of collisions along its northern, 
northwestern and southern margins (Fig. 1). The area affected by compressional deformation increased through the Jurassic, but without additional collisions at the margins of the SCB. Cretaceous extension formed large continental basins with 2 to 5 km thick terrigenous sedimentary deposits (Fig. 2; Shu et al., 2009; Li JH et al., 2012).

Although exhumation of the XFSB occurred in response to both the Early and Late Mesozoic tectonics of the SCB, the final exhumation and the related thermal evolution history remain poorly understood. This knov led ̨ e gap leaves a deficit in our wider understanding of the Mesozoic evolutir $n$ oi the SCB. Our new thermochronology data for the XFSB helps $r$ ri ge this gap. By comparing cooling paths obtained from different regions $\mathrm{st}$, he $\mathrm{N}$ CB with our new data, we discuss the widespread delayed exhumation $\mathrm{c}^{\mathrm{c}}$ the Triassic orogens, the implications for Mesozoic tectonics in South Chin . nd the more general issue of the relative timing of deformation and exhuma ion in orogenic belts and plateaux.

\section{Geological settin:}

\subsection{The South China Block}

The SCB is one of the major continental blocks in East Asia, and consists of the Yangtze and the Cathaysia Blocks to the northwest and southeast, respectively (Fig. 1). The amalgamation of the two blocks occurred in the Neoproterozoic, and gave rise to subduction-collision-related rock formations, including arc-related magmatic and sedimentary rocks between 1.0 and $0.9 \mathrm{Ga}$ (Li, 1999; Li et al., 2009; Wang et al., 
2013, 2016), metamorphic units (1.1-0.9 Ga) (Li et al., 2002, 2007), and post-orogenic intrusions (0.83-0.8 Ga) (Wang et al., 2006; Zheng et al., 2008).

An Early Paleozoic ( 460 to $380 \mathrm{Ma}$ ) tectonic event interrupted the continuous sedimentation since Late Neoproterozoic times, and strongly reworked the SCB by widespread compression. This intracontinental belt, called the Wuyi-Yunkai orogen, is characterized by amphibolite to granulite facies metamorphism, migmatization, and intensive deformation (Lin et al., 2008; Faure et al., 2009: 2 at al., 2010; Chu et al., 2012c, 2014; Shu et al., 2014). A regional Middle to L te l 'evonian unconformity marks the end of this tectonic event (BGMRJX, 1 984, BGMRHN, 1988; Shu et al., 2015).

Deformation affected the entire $s(3(1 \mathrm{~g} .1)$ in the Triassic. The Qinling-Dabie-Sulu orogen recorc- Triassic intracontinental subduction of the SCB under the North China Block, and in :ludes one of the largest areas of ultrahigh pressure metamorphic rock ^on Earth (Hacker et al., 2000; Meng and Zhang, 2000; Ratschbacher et al., 2 $\sim_{\sim}$; ; - aure et al., 2001, 2003). In the southwest, after Permian-Early Triassı : South-directed oceanic subduction, the Indochina Block collided with the SCB in the late Early to early Middle Triassic (ca 245-235 Ma) leading to the formation of the Indosinian Orogen (Lepvrier et al., 2004, 2011; Faure et al., 2014, 2016a). In the northwest part of the SCB, Triassic compression was responsible for crustal shortening in the Longmenshan Belt (e. g. Harrowfield and Wilson, 2005; Yan et al., 2011; Xue et al., 2017). 
Triassic NW-SE compression formed a broad intracontinental thrust belt from the southeast coastal region of the $\mathrm{SCB}$, to the northwest inland area, in response to the Paleo-Pacific subduction (Wang et al., 2005; Li and Li, 2007; Xu et al., 2011; Chu et al., 2012a, 2012b, 2018; Shu et al., 2015). A flat-slab subduction model has been proposed, which matches the northwest migration of magmatism ( $\mathrm{Li}$ and $\mathrm{Li}, 2007)$. There was a short period in the Late Triassic with post-orogenic magmatism and basin deposition (Li and Li, 2007; Shu et al., 2009). Continental _is stı sediments ("molasse") were deposited at the margins of the SCB 'e.g. Meng et al., 2005; Qiu et al., 2017). Crustal melt granites produce evidenc . for najor crustal thickening (e.g. He et al., 2010). Later Jurassic and Early $\mathrm{Cr}$ ‘ a $^{\prime}$, eous compressional tectonics partially reactivated the Triassic belts, and $\operatorname{adv} \mathrm{Anc} \geq \mathrm{d}$ lie thrust front westwards to the eastern Sichuan Basin (Li et al., 2018), pi -ducing a broad zone of distributed deformation (Fig. 1).

Cretaceous extension ${ }^{1}$ tectonics in the SCB has been recorded in numerous

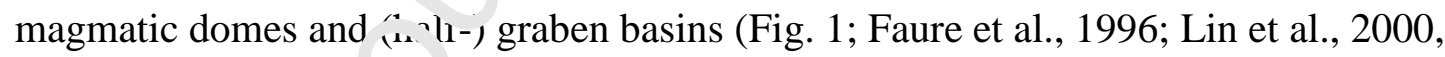
2015; Shu et al., 2005 Xu and Wang, 2010; Zhu et al., 2010; Li et al., 2013, 2014; Ji et al., 2018a, 2018b). As a continent-scale response to back-arc extension west of the Paleo-Pacific subduction, Cretaceous extension was coeval with several episodes of magmatic flare-ups (Li XH, 2000; Zhou et al., 2006; Li XH et al., 2010; Li ZX et al., 2012; Li JH et al., 2014; Jiang et al., 2015). In this period, episodic extension and compression alternatively controlled the tectonics of the SCB, suggested to relate to changes of subduction angle of the Paleo-Pacific slab (Zhou et al., 2006; Li et al., 
2010; Li et al., 2014; Jiang et al., 2015; Chu et al., 2018). Extensional domes with detachment zones document at least two episodes of extension-related ductile shearing and exhumation at $\sim 140-120 \mathrm{Ma}$ and $\sim 110-85 \mathrm{Ma}$, respectively, before and after a short ( 10 Myr) compressional event (Webb et al., 1999; Hacker et al., 2000; Lin et al., 2000; Ratschbacher et al., 2000; Zhu et al., 2010; Li et al., 2013, 2016, 2020; Ji et al., 2017, 2018a).

\subsection{The Xuefengshan Belt}

Located in the center of the SCB, the Xuef $\operatorname{lgs}$ an Belt (XFSB) is present for $>500 \mathrm{~km}$ along strike from the NE to the $\mathrm{s}$ (Fig. 2). Although the final establishment of this belt took place $j_{1}$ tt $\geqslant$ Late Mesozoic (Dong et al., 2015), the Middle Triassic compressional ev nt accounts for most of the present tectonic architecture. These structures are ( $\mathrm{V}$ 'rlain by a regional Late Triassic-Early Jurassic unconformity (Wang et al., ?005; Chu et al., 2012a, 2012b; Faure et al., 2016b). Beneath Neoproteroz is to ¿arly Triassic non-metamorphic sedimentary formations, a mylonitized décolleı nent zone and its underlying metamorphic rocks correspond to the orogenic cores of the XFSB, which were deformed and metamorphosed between 245 and $225 \mathrm{Ma}$ (Chu et al., 2012a, 2012b). By placing unmetamorphosed rocks over metamorphic rocks, the shear sense of this zone would appear to record an extensional overprinting after the Triassic compressional deformation. Undeformed post-orogenic Middle to Late Triassic granites ( 225-215 Ma) intruded into the folded pre-late Triassic strata (Chu et al., 2012c). The XFSB was also deformed by a Late 
Jurassic-Early Cretaceous compressional event. This event included the reactivation of previous thrust faults, and the formation of folds and thrusts involving Jurassic sedimentary rocks (Yan et al., 2003; Li et al., 2012; Dong et al., 2015). Unlike the Triassic structures, the Jurassic-Early Cretaceous structures were predominantly formed by brittle deformation. Cretaceous sedimentary basins are bounded by normal faults or detachments and contain several-hundred-meter- to kilometer-thick continental reddish conglomerate, sandstone, and siltstone (I GıIRHN, 1988; Shu et al., 2009; Li et al., 2014). On the basin footwalls, the $\mathrm{e}$ rhu ned rocks consist of ductilely deformed and metamorphosed micaschi it, o, weakly deformed rocks exposed in extensional domes or in horsts $\mathrm{b}, \mathrm{u}$. ded by high-angle brittle normal faults, respectively (Li et al., 2013; Ji et al., Tol 3a; Shu et al., 2019).

\section{Deformation in the orogenic er re of the Xuefengshan Belt}

\subsection{Triassic mylonitizatio. $\left(D_{1}\right)$}

The orogenic or a $9 i$ ine XFSB is exclusively exposed in the Eastern Zone as two localized domal-s laped metamorphic units, namely the North Orogenic Core (NOC), SW of Xinhua County, and the South Orogenic Core (SOC), East of Chengbu County (Fig. 2). Both the NOC and SOC include micaschist, quartzite, and deformed Early Paleozoic granite, which experienced medium to high greenschist facies metamorphism, pervasive ductile shearing, and mylonitization (Chu et al., 2012b). In the NOC and SOC these Paleozoic granites are the Baimashan and Miaoershan plutons, respectively (Fig. 2). 
The SOC shows dominant Triassic ductile deformation characterized by sub-horizontal flat-lying, but undulating foliation $\left(\mathrm{S}_{1}\right)$, and NW-SE mineral and stretching lineation $\left(\mathrm{L}_{1}\right)$, with a top-to-the NW sense of shear (Figs. 2 and 3a-b; Chu et al., 2012b). The amount of strain in these mylonitized quartzite and two-mica schist is in high contrast with the overlying, weakly metamorphosed and folded sandstone and siltstone. Syn-metamorphic monazite yields U-Th-Pb chemical ages at $\sim 245-225$ Ma interpreted as the time of mylonitization (Chu et al., 2 r,i2h). The NOC has a dome-shaped structure with NW- or SE-dipping foliati on $\left(i_{1}\right)$ and a NW-SE lineation $\left(\mathrm{L}_{1}\right)$ formed by a consistent top-to-the NW sheari ig a ring the Triassic (Figs. 5a-b). Within the ductile decollement, the Baimais ${ }^{1}$ al nluton was strongly deformed, showing intense mylonitization at its na, gins.

\subsection{Post-Triassic deformation}

A distinct late, althouc ${ }_{c}^{-h}$ weak, tectonic overprint of the Triassic structures is also present. The my ${ }^{1}$ in ${ }^{\prime} l c$ ioliation of the décollement zone was strongly crenulated by small upright folds with a wavelength of 0.2 to $1 \mathrm{~cm}$, and 1 - to $10 \mathrm{~m}$-scale folds during a late event (Figs. 4a-b). Both the Triassic foliation and lineation are folded by crenulation folds with closely spaced hinge lines (Figs. 4c-d; Chu, 2011). We observe an eastwards decrease in the amount of modification of the primary fabrics in the SOC. Close to the western boundary between the ductile décollement zone and the sedimentary cover, a low-grade metamorphosed pelitic rock is overprinted by strong crenulation, with hinge lines spaced at $0.1-0.5 \mathrm{~mm}$, which could have been initiated in 
the fine-grained layers (Fig. 4e). In the center of the SOC, the crenulation is weaker in medium-grade metamorphic rocks. Within two-mica schist, a well-developed crenulation with an obvious northwestward asymmetry only appears in the mica-rich layers, but its $0.5-2 \mathrm{~mm}$ wavelength is larger than in the western boundary (Fig. 4f). In the eastern boundary of the décollement zone, the crenulation deformation only generated gently asymmetric small folds with a large wavelength $>2 \mathrm{~mm}$ (Fig. $4 \mathrm{~g}$ ). Thus, our structural analysis suggests more intense tecton' _. 'ocification of the $D_{1}$ fabrics at the western boundary of the décollement zor $\geq$ th: $n$ the eastern one. The age of this modification is not clear.

In the NOC, crenulation folded the Tri ${ }_{\iota} S_{i} i r$ foliation in metasedimentary rocks, but barely affected the rigid mylonitiz ed ran te (Fig. 5a-b). The $S_{1}$ of the micaschist or metapelite is variably modifiea $\eta$ this area, and both closely-spaced and widely-spaced crenulation cleavąe ' $S_{c}$ ) can be observed. This tectonic overprinting is comparable with that of the SOC, suggesting a later event after the Triassic mylonitization during 1 iurmation of the XFSB.

\section{Sample descriptions}

In order to determine the cooling history of the orogenic core of the XFSB, a total of 12 samples were collected, with 10 from the SOC (Figs. 3a and Figs. 4a-f), and 2 from the NOC (Fig. 5).

In the SOC (Fig. 3), we chose an undeformed biotite monzogranite sample XF270 from the Miaoershan pluton that was emplaced at $412 \pm 4 \mathrm{Ma}$ (Chu et al., 
2012c). XF270 shows a dominant magmatic texture, but some $0.1-0.5 \mathrm{~mm}$ neograins developed at large quartz grain boundaries suggest the initiation of bulging recrystallization (Fig. 4d). Samples XF313 and XF314 are two mylonitic biotite granites from a sheared Early Paleozoic pluton dated at $418 \pm 3$ Ma in the SOC (Chu, 2012c).

Seven strongly deformed or mylonitized micaschist samples were also selected. Two mylonitic quartz micaschists, XF295 and XF296, and wee micaschist XF300 sampled in the north of the SOC include well-crenulat $\mathrm{d} m$ ca-rich layers resulting from a late overprinting (Figs. 4a and 4f). In the $r$ ente $\cdot$ of the SOC, XF316B and XF368 are micaschists deformed by the Tria ss _ ductile shearing and a late crenulation; muscovite/biotite grains se rit.ted along the mylonitic foliation, but also affected by microscopic folds. In the southern part of the SOC, we collected two garnet micaschist samples, XF312 ard XF365, both of which are located close to the décollement zone beneath $\imath$, Neoproterozoic cover, on the eastern and western flanks of the antiform of the $\mathrm{s} \mathcal{C}$. These micaschists are intensely sheared. Monazite chemical dating of sa uple XF365 places an age constraint of 225 Ma on the metamorphism coeval with ductile deformation (Chu et al., 2012b). As noted in section 3 , the intensity of crenulation, qualitatively estimated by the microfold wavelength, deceases from west (sample XF365) to east (sample XF312) (Figs. 4e and $4 \mathrm{~g})$.

In the NOC, we collected two deformed granite samples, XF224 and XF349 (Fig. 5a). Both samples are biotite monzogranite from the Early Paleozoic Baimashan 
pluton, which was emplaced at $411 \pm 4 \mathrm{Ma}$ (Chu et al., 2012c). In both samples, field and microscopic observations show similar deformation features, and kinematics. The Triassic synmetamorphic deformation temperature was estimated around $300-400^{\circ} \mathrm{C}$ from quartz c axis fabrics (Chu et al., 2012b). The late structural superimposition described in section 3 is not observed in this deformed granite.

\section{Analytical methods}

\section{1. ${ }^{40} \mathrm{Ar}-{ }^{39} \mathrm{Ar}$ dating}

Biotite, muscovite and K-feldspar grains we re s parated from mylonitic micaschist, quartzite and granites by conven 10 al mineral separation techniques, and handpicked under a binocular micros op to emove visible impurities. Except for samples XF295 and XF365, all ${ }^{40}$ i $r{ }^{39}$ Ar analyses were performed using a MM-5400 mass spectrometer at the ${ }^{40} \mathrm{Ar} /{ }^{39} \mathrm{~A}$ a $\mathrm{id}(\mathrm{U}-\mathrm{Th}) / \mathrm{He}$ Laboratory, Institute of Geology and Geophysics, Chinese A 'ademy of Sciences (IGGCAS, Beijing). Detailed analytical procedure r.m unscribed in Wang et al. (2014). Corrections on the measured isotopic rat is were for system blanks, mass discrimination, and irradiation-induced interference. ${ }^{40} \mathrm{Ar} /{ }^{39} \mathrm{Ar}$ ages were calculated on ${ }^{40} \mathrm{Ar} /{ }^{39} \mathrm{Ar} \mathrm{K}_{\mathrm{K}}$ ratios and $\mathbf{J}$ value from analyses of the monitors and the decay constant. Minerals from sample XF295 and XF365 were processed in Geosciences Montpellier (University of Montpellier). The detailed procedures were described by Monié and Agard (2009). Weighted plateau, inverse isochron and total fusion ages were calculated using the ArArCALC software (Koppers, 2002). Age data are presented with 2-sigma 
uncertainties. For analyses on K-feldspar, the various model parameters, e.g. active energy and relative domain size were processed with appropriate adjustment.

Multi-domain diffusion modeling was conducted to obtain a modeled age spectrum and cooling history.

\section{2. (U-Th)/He dating}

Zircon and apatite separation were conducted in the san ne procedure as for mica and feldspar. We performed the analyses at the ${ }^{40} \mathrm{Ar} /{ }^{39} . \mathrm{Ir}$ a) $\mathrm{d}(\mathrm{U}-\mathrm{Th}) / \mathrm{He}$ Laboratory, Institute of Geology and Geophysics, Chinese Ar ıdeı y of Sciences (IGGCAS, Beijing). Euhedral apatite and zircon grains ve e handpicked for inclusion-free grains under a high-power microscope, and ne packaged in $\mathrm{Pt}$ (for apatite) and $\mathrm{Nb}$ (for zircon) microtubes for (U-Th)/He tating analysis. Detailed parameters and procedures were presented by Wu et al. (2016) snd Shi et al. (2018). Standard minerals were used to verify the analytical proc dure: Durango apatite (dated at $32.2 \pm 1.0 \mathrm{Ma}$ by $\mathrm{Wu}$ et al., 2016, and 31.9 \pm 1.. Nia by Reiners and Nicolescu, 2006), and Fish Canyon Tuff zircon (dated at $28.3=2.6 \mathrm{Ma}$; Reiners, 2005).

\section{Results}

We obtained $11{ }^{40} \mathrm{Ar}-{ }^{39} \mathrm{Ar}$ results on biotite or muscovite, and 2 on K-feldspar by conventional step-heating method (Figs. 5 and 6; Tables S1-S3). The age spectra for mica are shown in Figs. 7 and 8, and K-feldspar analytical and modeled age 
spectra and cooling paths are shown in Fig. 9. We also acquired 3 zircon (U-Th)/He (ZHe) and 2 apatite (U-Th)/He (AHe) ages (Tables S4 and S5).

\subsection{Mica ${ }^{40} \mathrm{Ar}-{ }^{39} \mathrm{Ar}$ dating}

All mica dating results are within the age range 150-88 Ma, and 10 ages are clustered in the Early Cretaceous (Figs. 7 and 8; Table S1 and S2). Initial ${ }^{40} \mathrm{Ar} /{ }^{36} \mathrm{Ar}$ ratios are calculated for all samples, whereas those of XF2? - and XF365 are poorly constrained due to the narrow range of their ${ }^{40} \mathrm{Ar} /{ }^{39} \mathrm{Ar}$. atio : (Table S2). All the initial ${ }^{40} \mathrm{Ar} /{ }^{36} \mathrm{Ar}$ ratios are close to 295 , indicating neglic 1 ble excess argon in the dated minerals (Table S1). Except for XF300 and '.5 314, all samples have weighted plateau ages that are consistent with their tot? th sion ages and inverse isochron ages within errors (Figs. 7 and 8). The weighi $d$ plateau age (107.9 $\pm 3.6 \mathrm{Ma})$ of sample XF314 is 10 Myr younger than its total fus o'ı age (119.6 $\pm 3.4 \mathrm{Ma})$, whereas XF300 has a rugged age spectrum associ. ted with different amounts of released ${ }^{39} \mathrm{Ar}$. Indeed, most samples show unever u. $_{c}^{\mathrm{T}}$ spectra, possibly indicating a later thermal perturbation.

In the SOC, unc :formed granite sample XF270 from the Miaoershan pluton yields a biotite ${ }^{40} \mathrm{Ar}^{39} \mathrm{Ar}$ weighted plateau age at $143.4 \pm 3.4 \mathrm{Ma}$ (Fig. 7a). Two sheared granite samples XF313 and XF314 are dated at 124.8 \pm 5.7 Ma and $116.8 \pm$ 1.2 Ma respectively (Figs. 7d-e). Ages from micaschists vary in a more concentrated range at 132-136 Ma, but sample XF300 gives a much younger total fusion age of $108.8 \pm 1.4 \mathrm{Ma}$. Sample XF224 from the NOC yields a late Cretaceous age of $\sim 88 \mathrm{Ma}$ (Fig. 7h). 


\subsection{K-feldspar ${ }^{40} \mathrm{Ar}-{ }^{39} \mathrm{Ar}$ results and multi-domain diffusion modelling}

Two K-feldspar samples, XF270 from the Miaoershan pluton, and XF349 from the Baimashan pluton, have been analyzed by the high-resolution ${ }^{40} \mathrm{Ar}-{ }^{39} \mathrm{Ar}$ step-heating method (McDougall and Harrison, 1999). The multi-domain diffusion model of the ${ }^{40} \mathrm{Ar}^{39}{ }^{39} \mathrm{Ar}$ system in K-feldspar is the most widely used method for reconstructing the thermal evolution at $150-350^{\circ} \mathrm{C}$ (Lover . c: al., 1997, 2002; McDougall and Harrison, 1999).

Both samples show several rugged steps at ow emperatures because of excess Ar present in the margin of the mineral. The ag - spectra of sample XF270 range from $56 \mathrm{Ma}$ to $164 \mathrm{Ma}$ with a total fusion ? ge If $121 \mathrm{Ma}$ (Fig. 9a), which is close to its biotite ${ }^{40} \mathrm{Ar}^{39}{ }^{39} \mathrm{Ar}$ age. A small age ?lateau is shown around $128 \mathrm{Ma}$ with $18 \%$ of the total released argon, suggesting a ar id cooling event at this time. Cooling history demonstrates a fast cooling from $155 \mathrm{Ma}$ to $125 \mathrm{Ma}$, and fits well with the total fusion

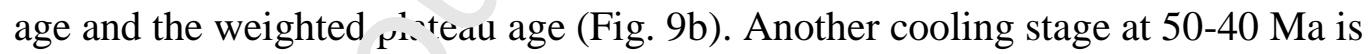
indicated at the end on this curve, but it has low reliability because the majority of the curve is in the low-temperature domain $\left(<150^{\circ} \mathrm{C}\right)$.

Sample XF349 has age spectra between $116 \mathrm{Ma}$ and $289 \mathrm{Ma}$ with a total fusion age at $222 \mathrm{Ma}$ (Fig. 9c). The relatively flat portion with $22 \%$ of the total released argon yields a weighted plateau age at $221 \mathrm{Ma}$ in agreement with the total fusion age. Multi-domain diffusion modeling reveals two stages of fast cooling; one from $255 \mathrm{Ma}$ 
to $220 \mathrm{Ma}$ that complies with the total fusion age and the weighted plateau age, and the other from $105 \mathrm{Ma}$ to $80 \mathrm{Ma}$ (Fig. 9d).

\section{3. (U-Th)/He dating}

All samples for ZHe and AHe dating are collected from the SOC (Fig. 6). ZHe ages from samples XF296, XF313, and XF368 range from 100 Ma to 77 Ma. XF296 has a Late Cretaceous AHe age of $78 \mathrm{Ma}$. Thus, according w the closure temperatures for $\mathrm{ZHe}$ and $\mathrm{AHe}$ of $185 \pm 10^{\circ} \mathrm{C}$, and $65 \pm 5^{\circ} \mathrm{C}$, respec ives y (Wolf et al., 1996; Farley, 2002; Reiners et al., 2002; Reiners, 2005), these $r$ suı s show that the southern core of the XFSB experienced relatively fast coolins, a a rate at $\sim 8^{\circ} \mathrm{C} / \mathrm{Myr}$ during the Late Cretaceous. In contrast, sample XF36, y zlas a Late Jurassic AHe age with large uncertainties, that is older than the $7 \mathrm{He}$ age of this sample. Considering the ${ }^{40} \mathrm{Ar}-{ }^{39} \mathrm{Ar}$ ages that are exclusively younoer $\mathrm{h} \approx \mathrm{n} 150 \mathrm{Ma}$, the AHe age of XF368 likely reflects a mixed result due to partia. resetting on the isotopic system.

\section{Discussion}

\subsection{Tectonothermal history of the Xuefengshan Belt}

Previous structural studies have demonstrated the dominance of Triassic tectonics in the development of the XFSB (Wang et al., 2005; Chu et al., 2012a, 2015). Recent work on the ductile décollement zone gives an Early Triassic age (ca. 245-225 Ma) for the syn-tectonic metamorphism of the garnet-micaschist (Chu, 2011; Chu et al., 2012b). In the NOC, our new data clearly indicate this Early Triassic 
tectono-thermal event underwent a $2-3^{\circ} \mathrm{C} / \mathrm{Myr}$ cooling gradient in the modeled thermal history of the Baimashan pluton (Fig. 9b). The thermal history for the Baimashan pluton also documents a fast cooling at $~ 100-85 \mathrm{Ma}$, consistent with the biotite ${ }^{40} \mathrm{Ar}-{ }^{39} \mathrm{Ar}$ age at $\sim 88 \mathrm{Ma}$ (Fig. 9b).

In the SOC, structural observations reveal a second deformation phase that reworked the Triassic structures by pervasive crenulation cleavages. The development of these crenulations was coeval with a low-temperature c.u.nnit of the previous structures as the result of reactivation along the décollı mer $t$ zone. Our thermochronology results indicate that the overpr nt t ok place in the Late Jurassic-Early Cretaceous, and may have rea $\mathrm{n} \cdot \mathrm{d}$ a peak at $\sim 130 \mathrm{Ma}$, as documented by the ${ }^{40} \mathrm{Ar}-{ }^{39} \mathrm{Ar}$ ages (Fig. 9). Indeed th Crstaceous event observed in the SOC has a similar timing and style to the $e_{\wedge}{ }^{+}$ensional tectonics in the adjacent Yuechengling pluton, where a large-scale detach $\mathrm{n} \_\mathrm{nt}$ accommodated extensional exhumation of the dome structure (Chu et al., . 919 ). In the northwest part of the XFSB, Cretaceous extension also former : : rg continental basins with shallow to semi-deep lake facies deposits (Tang et al., . 014).

The K-feldspar modeled cooling history from the undeformed part of the Miaoershan pluton shows that a fast cooling stage began at $\sim 160 \mathrm{Ma}$, and lasted until $\sim 130 \mathrm{Ma}$, at an overall exhumation rate of $\sim 4^{\circ} \mathrm{C} / \mathrm{Myr}$ (Fig. 9). In the XFSB, the late Jurassic-earliest Cretaceous compression is followed by Early Cretaceous extension (BGMRHN, 1988; Shu et al., 2009; Li et al., 2014), but the transition between compression and extension are still debated (Zhou and Li, 2000; Dong et al., 2008, 
2015). The incipient cooling of the Miaoershan pluton at $160 \mathrm{Ma}$ (ca. $10 \mathrm{Myr}$ earlier than the earliest ${ }^{40} \mathrm{Ar}^{39}{ }^{39} \mathrm{Ar}$ age recorded in the SOC), took place in a transitional stage between the Middle-Late Jurassic extension, and the Late Jurassic-Early Cretaceous regional compression of the SCB (Zhou and Li, 2000; Li et al., 2014).

Metamorphic rocks from the SOC do not yield any Late Cretaceous ${ }^{40} \mathrm{Ar}^{39} \mathrm{Ar}$ ages, which suggests they were already at upper crustal depths before the second phase of exhumation at this time (Fig. 10). ZHe and AHe ges piovide a well-constrained cooling pattern in which fast cooling ron $\sim 7 \pm 1 \mathrm{~km}$ to $\sim 3 \pm 1 \mathrm{~km}$ occurred at $\sim 100-80 \mathrm{Ma}$ in the SOC, but Late Cre ace sus exhumation of the NOC began at a deeper level, at depths of $\sim 12 \pm 2 \mathrm{kr}^{\prime}$. (assuming an average paleo-temperature gradient of $\left.25^{\circ} \mathrm{C} / \mathrm{k} n\right)$.

To summarize, the NOC rec $、$ rds an Early Triassic thermal event, overprinted by a Late Cretaceous cooling event, $\mathbf{r}$ ' $\mathrm{h}$ reas the SOC shows a two-stage cooling path in the Early and Late Cretace is periods (Fig. 10). In spite of the internal variations during the exhumatic.., the XFSB experienced a two-stage exhumation in the Late Mesozoic: one from $\sim 150 \mathrm{Ma}$ to $110 \mathrm{Ma}$, centered at $\sim 130 \mathrm{Ma}$, and another one between $\sim 100-80$ Ma (Fig. 9). The two-stage exhumation pattern is also identified in the adjacent regions of the XFSB. To the SE of the SOC, the Yuechengling pluton, (Fig. 2), preserved two phases of ductile extensional deformation that took place at 140-120 Ma and 100-85 Ma respectively (Chu et al., 2019). The Hengshan detachment initiated in the Early Cretaceous (Fig. 2), and was followed by a Late Cretaceous cooling event (Li et al., 2013; Wei et al., 2016). Fault slip analysis in the 
Yuanma Basin also demonstrates two stages of $\sim$ NW-SE extension in the Early and

Late Cretaceous, respectively (Li et al., 2012). Therefore, all of these lines of evidence support a two-stage-extensional history across the XFSB in the Late Mesozoic, principally in the Early and Late Cretaceous (Fig. 10).

\subsection{Regional Cretaceous exhumation of Triassic orogens: implications for the}

\section{destruction of the Mesozoic plateau in South China}

Triassic tectonics had a major impact across the $\mathrm{CB}$ creating a wide intracontinental fold-and-thrust belt that probably resı mbled an Andean-type orogenic plateau, superimposed on the crustal thicken ny, caused by the continental collisions along its northern and southern margi . IS I Yitı and Nie, 1996; Li and Li, 2007; Chu et al., 2012a). During the Late Triass: to Early Jurassic, A-type and basaltic magmatism implies signatures of the asthenos $\mathbf{l}$ ' ric mantle, but the Triassic orogenic plateau was preserved during the follow ing compression (Li et al., 2014).

We propose a $\mathrm{r}^{\mathrm{d}} \mathrm{de}_{\mathbf{1}}$ unat regional exhumation and destruction of this plateau occurred in the Cretac sous, and here review the regional evidence that supports this model (Fig. 11). At the northern margin of the SCB, post-orogenic extension of the Early Mesozoic high pressure-ultrahigh pressure Qinling-Dabieshan-Sulu belt gave rise to a fast cooling phase in the Late Triassic-Early Jurassic (Figs. 1 and 11), but the Early Cretaceous large-scale extension also exposed a large portion of the exposed UHP and high temperature metamorphic units at 130-120 Ma (Ratschbacher et al., 2000; Lin et al., 2015; Ji et al., 2017). As the western extension of the Dabieshan belt, 
the Triassic Tongbaishan belt was also overprinted by two stages of ductile extension that exhumed a large portion of the high pressure rocks during the Early and Late Cretaceous eras (Fig. 11a) (Webb et al., 1999; Liu et al., 2010; Xu and Wang, 2010; Cui et al., 2012).

Our new results argue for similar Cretaceous overprinting of the Triassic XFSB (Fig. 11b). The décollement zone that represents the orogenic core of this belt developed during the Early Triassic, but its final exhumat ${ }_{\text {un }}{ }^{t} \mathrm{O}$ the upper crustal or subaerial level was completed in the Late Cretaceous, ollo ving an Early Cretaceous stage of exhumation (Fig. 11b). In the southern p: rt o the SCB, the Triassic orogenic events deformed the early Paleozoic deform $\mathrm{a}$, nd metamorphosed rocks in the Yunkai, Baiyunshan, and Song Chay va sits (Fig. 1; Roger et al., 2000; Wang et al., 2007; Wan et al., 2010; Chen et a. 2011, 2017), while the Cretaceous extension exhumed the Triassic basement w th a fast cooling stage at $~ 140-120$ Ma (Fig. 11b), and played an important ro: in the formation of the present orogenic configuration

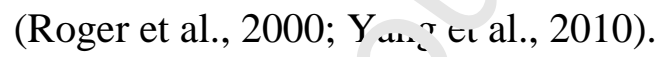

Delayed exhum, tion of the Triassic orogenic belts appears to be a common phenomenon across the SCB (Fig. 12). Despite variations in exhumation rates and patterns, this widespread Cretaceous extension shows a connection to continental-scale extensional tectonics induced by Paleo-Pacific subduction (Fig. 12b; Li XH, 2000; Zhou and Li, 2000; Li and Li, 2007; Li JH et al., 2014; Ji et al., 2018a). The crust of the North China Block was profoundly extended in numerous metamorphic core complexes and (half-) graben basins in a short period at 130-120 
Ma. At depth, the NCB lithospheric mantle was also removed by effects of the Paleo-Pacific subduction (Lin and Wang, 2006; Wu et al., 2019). The SCB may have evolved under a contrasting regime. After the formation of the Triassic belts, a significant portion of orogenic cores, such as the XFSB, remained stagnant at the upper-middle crustal level (Fig. 10). Although compressional deformation may have played a role in the Jurassic tectonics of the SCB (Dong et al., 2008, 2015; Shu et al., 2009; Li et al., 2014), it had had limited impact on the coc".in. T paths from the pre-existing Triassic belts. The Triassic orogenic core inits retained their position in the crust (Figs. 10 and 11). In the Cretaceous, the lon $_{\varepsilon}$-lasting, episodic extension facilitated the exhumation of these orogenic $-\mathrm{O}$ es, most of which were exposed to their present, subaerial levels, as shor $\mathrm{n} \iota \mathrm{y} \mathrm{n}_{\mathrm{\imath}}$ tamorphosed/deformed pebbles in the Cretaceous basins (Fig. 12; Zhang at al., 2010; Chu et al., 2019).

The Triassic SCB probahly es embled other orogenic plateaux (Fig. 13), such as the North American Cordiii ra ( Nevadaplano") in the Late Mesozoic (Dickinson, 2004; Yonkee and W ¿is ' 15 ), the Late Cretaceous Lhasa terrane ("Lhasaplano"; Kapp et al., 2007; Wa ig et al., 2017), or the Cenozoic Central Andes (Altiplano and Puna plateaux; Espurt et al., 2008). All these regions are characterized by retroarc fold-and-thrust belts, which thickened the crust over broad regions. However, these plateaux have had different fates. The Nevadaplano was dismantled during Late Cenozoic extension (Colgan and Henry, 2009). The high elevation of the Lhasaplano was preserved because of the subsequent India-Eurasia collision that persisted or enhanced the compression (Wang et al., 2017). The Central Andean Plateau was built 
by compressional deformation since $\sim 40 \mathrm{Ma}$, and is still growing laterally and across strike (McQuarrie et al., 2008; Scott et al., 2018).

The implication of our study on the SCB plateau is that the other orogenic plateaux may have experienced (or will experience) similar long time lags between the construction of the belt, and widespread destruction by extension and exhumation of rocks to surface or near-surface levels. It is notable that this scenario implies little or no denudation throughout the Jurassic for the SCB, in $k_{\sim_{1}}$ ing with the lack of evidence for exhumation or tectonic deformation throu oh $\mathrm{t}$ is period, with the implication that erosional processes on their own wer not sufficient to reduce the Triassic plateau to near-normal crustal thick' er, and elevation.

Taking the present regional cru al hic iness of the interior of the SCB as $\sim 35$ $\mathrm{km}$ (He et al., 2014), and adding ${ }^{-1} 0 \mathrm{~km}$ as a very rough estimate of regional exhumation by the end of the Cret ic sous, gives an indicative Triassic crustal thickness of $\sim 45 \mathrm{~km}$. Whilc this figure is much less than crustal thicknesses in the modern Andean or $T^{i} u^{+} \eta_{1}$ plateaux, it is comparable with the interior of the Iranian Plateau (Taghizadeh-ı arahmand et al., 2015), and suggests that regional paleo-elevations may have been on the order of $1.5 \mathrm{~km}$ above sea level, by analogy with the modern Iranian plateau.

Present lateral dimensions of the paleo-SCB plateau are $\sim 1300 \mathrm{~km}$ northeast-southwest from the Qinling-Dabie-Sulu belts in the northeast to the Indosinian Orogen in the southwest (Fig. 1). The northwest-southeast dimension is harder to reconstruct, but potentially reached from the western margin of the 
Xuefengshan deep into the interior of the Cathaysia Block, which is a present-day distance of $\sim 500 \mathrm{~km}$ (Fig. 1). The total area involved is therefore $\sim 800,000 \mathrm{~km}^{2}$. This is comparable to the Central Andean Plateau, but smaller than the Turkish-Iranian or Tibetan plateaux $\left(\sim 1,400,000\right.$ and $2,000,000 \mathrm{~km}^{2}$ respectively). The paleo-SCB plateau should have been wider before the Cretaceous extension, but the initial width is unknown as the extension factor is not yet constrained.

\section{Conclusions}

A complex cooling path is recorded in the $r \operatorname{cog}_{\mathrm{c}}$ nic core of the XFSB. In this belt, Early Triassic ductile deformation prod $\mathrm{ACr} d$ a greenschist to lower amphibolite facies décollement zone overlying tw, o, ogt.ic cores. The northern core underwent Late Triassic extension, whereas ive southern orogenic core retained its middle crustal position through this time. Both co res underwent significant Cretaceous exhumation, but in different ways. The s vuthern orogenic core had a two-stage exhumation process, with Early Cretaceour whumation to $\sim 7 \pm 1 \mathrm{~km}$ depth, and Late Cretaceous exhumation to $\sim 3 \pm 1$ 'm depth. The northern orogenic core only underwent the Late Cretaceous stage that exhumed the rocks from $\sim 12 \pm 2 \mathrm{~km}$ to $\sim 6 \pm 1 \mathrm{~km}$ depth (Fig. 10). Combining the available evidence leads us to propose that the larger part of the SCB was an orogenic plateau from its construction in the Late Triassic until its destruction in the Late Cretaceous. This concept is no doubt a great simplification of a complex region, but it gives a new framework for understanding each facet of the geology. 
Comparison with other Triassic orogenic belts of the SCB (Fig. 11) indicates that such postponed exhumation may be a common phenomenon. Although the detailed exhumation history for each belt varies (Fig. 13), we emphasize the common importance of Cretaceous extension in the SCB, that established the present structure. Changes in stress state at the Paleo-Pacific plate boundary are the most likely cause of Cretaceous extension (Fig. 12), following a long period where an orogenic plateau of thick continental crust remained in equilibrium, neither $\mathrm{co}^{\prime \prime} \mathrm{ia}_{\mathbf{1}}{ }^{\top} \mathrm{s} 1 \mathrm{~g}$ nor enlarging.

\section{Acknowledgements}

This study was funded by the Ministry of Science and Technology (2016YFC0600401 and 2016YFC06P J1 2), he National Natural Science Foundation of China (91855212, 41872208, a. 4 41302161), the China Scholarship Council (201804910283), and the Youth fi nr vation Promotion Association. T. Francois, an anonymous reviewer, and $\mathrm{L}$ titor Phillipe Agard are acknowledged for their constructive comment. ${ }^{\wedge} n_{\mathrm{u}}$ suggestions. Mr. J.Y. Li is thanked for his help during the fieldwork, and Drs. P. Monié, L. Wu, and W.B. Shi are thanked for their assistance in the Ar-Ar and (U-Th)/He analysis. This work also benefited from the discussions in Coffice 442 of the Institute of Geology and Geophysics, Chinese Academy of Sciences.

\section{References}

Bureau of Geology and Mineral Resources of Hunan province (BGMRHN), 1988. 
Regional Geology of the Hunan Province. Geological Publishing House, Beijing. $507 \mathrm{pp}$.

Bureau of Geology and Mineral Resources of Jiangxi Province (BGMRJX), 1984.

Regional Geology of the Jiangxi Province. Geological Publishing House, Beijing. 921 pp.

Chen, C.-H., Hsieh, P.-S., Lee, C.-Y., Zhou, H.-W., 2011. Two episodes of the Indosinian thermal event on the South China Block: ¿ nsuraints from LA-ICPMS U-Pb zircon and electron microprob ‘ mo razite ages of the Darongshan S-type granitic suite. Gondwan a Rı s. 19, 1008-1023.

Chen, C.-H., Liu, Y.-H., Lee, C.-Y., Xiang, F.,, Žhou, H.-W., 2012. Geochronology of granulite, charnockite and gneis, 11 the poly-metamorphosed Gaozhou Complex (Yunkai massif), South Chiı^ Emphasis on the in-situ EMP monazite dating. Lithos 144-145, 109-129.

Chen, C.-H., Liu, Y.-H., Le. C.-Y., Sano, Y., Zhou, H.-W., Xiang, H., Takahata, N., 2017. The Trias is reworking of the Yunkai massif (South China): EMP monazite and $\mathrm{U} \cdot \mathrm{Pb}$ zircon geochronologic evidence. Tectonophysics 694, 1-22.

Chu, Y., Faure, M., Lin, W., Wang, Q., 2012a. Early Mesozoic tectonics of the South China block: Insights from the Xuefengshan intracontinental orogen. J Asian Earth Sci 61, 199-220.

Chu, Y., Faure, M., Lin, W., Wang, Q., Ji, W., 2012b. Tectonics of the Middle Triassic intracontinental Xuefengshan Belt, South China: new insights from structural and chronological constraints on the basal décollement zone. Int J Earth Sci 101, 
2125-2150.

Chu, Y., Lin, W., Faure, M., Wang, Q., Ji, W., 2012c. Phanerozoic tectonothermal events of the Xuefengshan Belt, central South China: Implications from U-Pb age and Lu-Hf determinations of granites. Lithos 150, 243-255.

Chu, Y., Lin, W., 2014. Phanerozoic polyorogenic deformation in southern Jiuling Massif, northern South China block: Constraints from structural analysis and geochronology. J Asian Earth Sci 86, 117-130.

Chu, Y., Lin, W., Faure, M., Wang, Q., 2015. Early Mc sozc ic intracontinental orogeny: Example of the Xuefengshan-Jiuling Belt. $\angle$ cta Petrol Sin 31, 2145-2155.

Chu, Y., Lin, W., 2018. Strain analysis of the X efengshan Belt, South China: From internal strain variation to form ،10 1 oi the orogenic curvature. J Struct Geol $116,131-145$.

Chu, Y., Lin, W., Faure, M., Xıe, '’. Ji, W., Wu, L., Feng, Z., 2019. Cretaceous episodic extension in . Soutn China Block, East Asia: Evidence from the Yuechengling N.m sli of central South China. Tectonics, 38. https://doi.org/1 ).1029/2019TC005516.

Colgan, J.P., Henry, C.D., 2009. Rapid middle Miocene collapse of the Mesozoic orogenic plateau in north-central Nevada. Int. Geol. Rev. 51, 920-961.

Cui, J., Liu, X., Dong, S., Hu, J., 2012. U-Pb and 40Ar/39Ar geochronology of the Tongbai complex, central China: Implications for Cretaceous exhumation and lateral extrusion of the Tongbai-Dabie HP/UHP terrane. J Asian Earth Sci 47, 155-170. 
Dickinson, W.R., 2004. Evolution of the North American Cordillera. Annu Rev Earth Planet Sci 32, 13-45.

Ding, X., Chen, P.R., Chen, W.F., Huang, H.Y., Zhou, X.M., 2005. LA-ICPMS zircon $\mathrm{U} \backslash \mathrm{Pb}$ age determination of the Weishan granite in Hunan: petrogenesis and significance. Science in China (D) 35, 606-616.

Dong, S., Zhang, Y., Long, C., Yang, Z., Ji, Q., Wang, T., Hu, J., Chen, X., 2008. Jurassic tectonic revolution in China and new interp" wtion of the "Yanshan Movement". Acta Geol. Sin. 82, 334-347.

Dong, S., Zhang, Y., Zhang, F., Cui, J., Chen, X. Zha g, S., Miao, L., Li, J., Shi, W., Li, Z., Huang, S., Li, H., 2015. Late Jv as sic-Early Cretaceous continental convergence and intracontinent $₫ 0$ og hesis in East Asia: A synthesis of the Yanshan Revolution. J. Asia. Earth Sci 114, 750-770.

Espurt, N., Funiciello, F., Martino 1. .., Guillaume, B., Regard, V., Faccenna, C., Brusset, S., 2008. Fla. subduction dynamics and deformation of the South American plate Is sisits from analog modeling. Tectonics 27, TC3011, $10.1029 / 2007$ tci 02175 .

Farley, K. A. (2002). (U-Th)/He dating: Techniques, calibrations, and applications, Reviews in Mineralogy and Geochemistry, 47, 819-844. https://doi.org/10.2138/rmg.2002.47.18.

Faure, M., Sun, Y., Shu, L., Monié, P., Charvet, J., 1996. Extensional tectonics within a subduction-type orogen. The case study of the Wugongshan dome (Jiangxi Province, southeastern China). Tectonophysics 263, 77-106. 
Faure, M., Lin, W., Shu, L.S., Sun, Y., Scharer, U., 1999. Tectonics of the Dabieshan (eastern China) and possible exhumation mechanism of ultra high-pressure rocks. Terra Nova 11, 251-258.

Faure, M., Lin, W., Le Breton, N., 2001. Where is the North China-South China block boundary in eastern China? Geology 29, 119-122.

Faure, M., Lin, W., Scharer, U., Shu, L.S., Sun, Y., Arnaud, N., 2003. Continental subduction and exhumation of UHP rocks. Structura'. a.' 'd yeochronological insights from the Dabieshan (East China). Lithos 70, 213-241.

Faure, M., Shu, L., Wang, B., Charvet, J., Choule , F., Monie, P., 2009. Intracontinental subduction: a possible $\mathrm{m}$-rhanism for the Early Palaeozoic

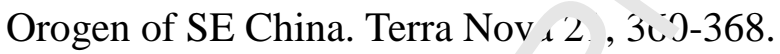

Faure, M., Lepvrier, C., Nguyen, ' V., Vu, T.V., Lin, W., Chen, Z., 2014. The South China block-Indochina colii ir n: Where, when, and how? J Asian Earth Sci 79, 260-274.

Faure, M., Lin, W., C'.n, I., Lepvrier, C., 2016a. Triassic tectonics of the Ailaoshan Belt (SW China : Early Triassic collision between the South China and Indochina Blocks, and Middle Triassic intracontinental shearing. Tectonophysics 683, 27-42.

Faure, M., Lin, W., Chu, Y., Lepvrier, C., 2016b. Triassic tectonics of the southern margin of the South China Block. C.R. Geosci. 348, 5-14.

François, T., Agard, P., Bernet, M., Meyer, B., Chung, S.L., Zarrinkoub, M.H., Burov, E., Monié, P., 2014. Cenozoic exhumation of the internal Zagros: first 
constraints from low-temperature thermochronology and implications for the build-up of the Iranian plateau. Lithos 206-207, 100-112.

Hacker, B.R., Ratschbacher, L., Webb, L., McWilliams, M.O., Ireland, T., Calvert, A., Dong, S.W., Wenk, H.R., Chateigner, D., 2000. Exhumation of ultrahigh-pressure continental crust in east central China: Late Triassic-Early Jurassic tectonic unroofing. Journal of Geophysical Research-Solid Earth 105, 13339-13364.

Harrowfield, M. J., Wilson, C. J. L., 2005. Indosinian ('efor mation of the Songpan Ganze Fold Belt, northeast Tibetan Plateau J. S ruct. Geol., 27, 101-117.

Harrison, T.M., Copeland, P., Kidd, W.S.F. a ı Yin, A., 1992. Raising Tibet. Science $255,1663-1670$.

He, Z.Y., Xu, X.S., Niu, Y.L., 201` Petrogenesis and tectonic significance of a Mesozoic granite-syenite-g ' $b^{\prime}$ 'sro association from inland South China. Lithos $119,621-641$.

He, R., Shang, X., Yv, , , Enang, H. and Van der Hilst, R.D., 2014. A unified map of Moho depth anc $\mathrm{Vp} / \mathrm{Vs}$ ratio of continental China by receiver function analysis. Geophysical Journal International, 199(3): 1910-1918.

Isacks, B. L. (1988), Uplift of the Central Andean Plateau and bending of the Bolivian Orocline, Journal of Geophysical Research-Solid Earth and Planets, 93(B4), $3211-3231$.

Ji, W., Lin, W., Faure, M., Shi, Y., Wang, Q., 2017. The early Cretaceous orogen-scale Dabieshan metamorphic core complex: implications for extensional collapse of 
the Triassic HP-UHP orogenic belt in east-central China. Int J Earth Sci 106, 1311-1340.

Ji, W., Faure, M., Lin, W., Chen, Y., Chu, Y., Xue, Z., 2018a. Multiple Emplacement and Exhumation History of the Late Mesozoic Dayunshan-Mufushan Batholith in Southeast China and Its Tectonic Significance: 1. Structural Analysis and Geochronological Constraints. Journal of Geophysical Research: Solid Earth $113,689-710$.

Ji, W., Chen, Y., Chen, K., Wei, W., Faure, M., Lin, W. 20 sb. Multiple Emplacement and Exhumation History of the Late Mesoz ic L'ayunshan-Mufushan Batholith in Southeast China and Its Tectonic $\mathrm{Si} r, \mathrm{n}$ icance: 2. Magnetic Fabrics and Gravity Survey. Journal of Geo'ny icai Research: Solid Earth 113, 711-731.

Jiang, X.-Y., Li, X.-H., Collins, W. '., Huang, H.-Q., 2015. U-Pb age and Hf-O isotopes of detrital zircons f or . Hainan Island: Implications for Mesozoic subduction models. L thos 239, 60-70.

Kapp, P., DeCelles, P 工 Luler, A.L., Fabijanic, J.M., He, S., Pullen, A., Gehrels, G.E., Ding, L., 2007. The Gangdese retroarc thrust belt revealed. GSA Today 17, 4. Koppers, A. A. P., 2002. ArArCALC—Software for 40Ar/39Ar age calculations. Computer \& Geosciences, 28, 605-619, doi:10.1016/S0098-3004(01)00095-4. Law, R., Allen, M.B., 2020. Diachronous Tibetan Plateau landscape evolution derived from lava field geomorphology. Geology 48, 263-267.

Lepvrier, C., Maluski, H., Van Tich, V., Leyreloup, A., Truong Thi, P., Van Vuong, N., 2004. The Early Triassic Indosinian orogeny in Vietnam (Truong Son Belt and 
Kontum Massif); implications for the geodynamic evolution of Indochina. Tectonophysics 393, 87-118.

Lepvrier, C., Van Vuong, N., Maluski, H., Truong Thi, P., Van Vu, T., 2008. Indosinian tectonics in Vietnam. Comptes Rendus Geosciences 340, 94-111.

Lepvrier, C., Faure, M., Van, V.N., Vu, T.V., Lin, W., Trong, T.T., Hoa, P.T., 2011.

North-directed Triassic nappes in Northeastern Vietnam (East Bac Bo). J Asian Earth Sci 41, 56-68.

Li, Y.H., Gao, M.T., Wu, Q.Y., 2014. Crustal thickness mas of the Chinese mainland from teleseismic receiver functions. Tecton (phy sics 611, 51-60.

Li, J., Zhang, Y., Dong, S., Li, H., 2012. Lat N esozoic-Early Cenozoic deformation history of the Yuanma Basin, ce. Itr. 1 Su ath China. Tectonophysics 570-571, 163-183.

Li, J., Zhang, Y., Dong, S., Su. J., j Y., Cui, J., Shi, W., 2013. The Hengshan low-angle normal fau ${ }^{+}$zone: Structural and geochronological constraints on the Late Mesozoic ... stai extension in South China. Tectonophysics 606, 97-115.

Li, J., Zhang, Y., Don, S., Johnston, S.T., 2014. Cretaceous tectonic evolution of South China: A preliminary synthesis. Earth-Science Reviews 134, 98-136. Li, J., Dong, S., Zhang, Y., Zhao, G., Johnston, S.T., Cui, J., Xin, Y., 2016. New insights into Phanerozoic tectonics of south China: Part 1, polyphase deformation in the Jiuling and Lianyunshan domains of the central Jiangnan Orogen. Journal of Geophysical Research: Solid Earth 121, 3048-3080.

Li, J., Dong, S., Cawood, P.A., Zhao, G., Johnston, S.T., Zhang, Y., Xin, Y., 2018. An 
Andean-type retro-arc foreland system beneath northwest South China revealed by SINOPROBE profiling. Earth Planet Sci Lett 490, 170-179.

Li, J., Cawood, P.A., Ratchbacher, L., Zhang, Y., Dong, S., Xin, Y., Yang, H., Zhang, P., 2020. Building Southeast China in the late Mesozoic: Insights from alternating episodes of shortening and extension along the Lianhuashan fault zone. Earth Science Reviews 201, 103056.

Li, S., Santosh, M., Zhao, G., Zhang, G. and Jin, C., 2011 in 'racontinental deformation in a frontier of super-convergence: pes spective on the tectonic milieu of the South China Block. Journal of Ası n Earth Sciences, 49: 313-329.

Li, X.H., 1999. U-Pb zircon ages of granites $₫ \mathbf{r}$ $m$ the southern margin of the Yangtze Block: timing of Neoproterozoi - $\mathbf{J} \mathbf{l n} 1 \mathbf{I}_{\mathrm{g}}$ : Orogeny in SE China and implications for Rodinia As``mbly. Precambrian Res 97, 43-57.

Li, X.-H., 2000. Cretaceous magn at sm and lithospheric extension in Southeast China. J Asian Earth Sci 18, ' 93-305.

Li, X.-H., Li, W.-X., '․, Z. X., Lo, C.-H., Wang, J., Ye, M.-F., Yang, Y.-H., 2009. Amalgamation ı etween the Yangtze and Cathaysia Blocks in South China: Constraints from SHRIMP U-Pb zircon ages, geochemistry and Nd-Hf isotopes of the Shuangxiwu volcanic rocks. Precambrian Res 174, 117-128.

Li, X.H., Li, W.X., Wang, X.C., Li, Q.L., Liu, Y., Tang, G.Q., Gao, Y.Y., Wu, F.Y., 2010. SIMS U-Pb zircon geochronology of porphyry $\mathrm{Cu}-\mathrm{Au}-(\mathrm{Mo})$ deposits in the Yangtze River Metallogenic Belt, eastern China: Magmatic response to early Cretaceous lithospheric extension. Lithos 119, 427-438. 
Li, Z.X., Li, X.H., Zhou, H.W., Kinny, P.D., 2002. Grenvillian continental collision in south China: New SHRIMP U-Pb zircon results and implications for the configuration of Rodinia. Geology 30, 163-166.

Li, Z.X., Li, X.H., 2007. Formation of the 1300-km-wide intracontinental orogen and postorogenic magmatic province in Mesozoic South China: A flat-slab subduction model. Geology 35, 179-182.

Li, Z.X., Wartho, J.A., Occhipinti, S., Zhang, C.L., Li, X.F., 'Vang, J., Bao, C.M., 2007. Early history of the eastern Sibao Orogen Sou h China) during the assembly of Rodinia: New mica Ar-40/Ar-29 da ing and SHRIMP U-Pb detrital zircon provenance constraints. Precam's in Res 159, 79-94.

Li, Z.-X., Li, X.-H., Wartho, J.-A., Cl „rk C., Li, W.-X., Zhang, C.-L., Bao, C., 2010. Magmatic and metamorphic svents during the early Paleozoic Wuyi-Yunkai orogeny, southeastern South C'lina: New age constraints and pressure-temperature 'onditions. Geol Soc Am Bull 122, 772-793.

Li, Z.-X., Li, X.-H., C..`活, S.-L., Lo, C.-H., Xu, X., Li, W.-X., 2012. Magmatic switch-on and s ritch-off along the South China continental margin since the Permian: Transition from an Andean-type to a Western Pacific-type plate boundary. Tectonophysics 532-535, 271-290.

Lin, W., Faure, M., Monie, P., Scharer, U., Zhang, L.S., Sun, Y., 2000. Tectonics of SE China: New insights from the Lushan massif (Jiangxi Province). Tectonics 19, $852-871$.

Lin, W., Wang, Q.C., 2006. Late Mesozoic extensional tectonics in the North China 
block: a crustal response to subcontinental mantle removal? Bull Soc Geol Fr $177,287-297$.

Lin, W., Wang, Q., Chen, K., 2008. Phanerozoic tectonics of south China block: New insights from the polyphase deformation in the Yunkai massif. Tectonics 27.

Lin, W., Shi, Y., Wang, Q., 2009. Exhumation tectonics of the HP-UHP orogenic belt in Eastern China: New structural-petrological insights from the Tongcheng massif, Eastern Dabieshan. Lithos 109.

Lin, W., Ji, W., Faure, M., Wu, L., Li, Q., Shi, Y., Scha er, IJ., Wang, F., Wang, Q., 2015. Early Cretaceous extensional reworking $c^{f}$ the Triassic HP-UHP metamorphic orogen in Eastern China it ¿tonophysics 662, 256-270.

Lin, W., Wei, W., 2019. Late Mesozo; $\_$e. ten ional tectonics in the North China Craton and its adjacent regi ns: a review and synthesis. Int Geo Rev, https://doi.org/10.1080/00'¿C 58 14.2018.1477073.

Liu, X., Jahn, B.-m., Cui, J., Li, S., Wu, Y., Li, X.-h., 2010. Triassic retrograded eclogites and $\mathrm{C}:{ }^{\mathrm{a}} \mathrm{c}$ uus gneissic granites in the Tongbai Complex, central China: Implicatı sns for the architecture of the HP/UHP Tongbai-Dabie-Sulu collision zone. Lithos 119, 211-237.

Lovera, O.M., Grove, M., Harrison, T.M., Mahon, K.I., 1997. Systematic analysis of K- feldspar 40Ar/39Ar step heating results: I. Significance of activation energy determinations. Geochimica et Cosmochimica Acta 61, 3171-3192.

Lovera, O.M., Grove, M., Harrison, T.M., 2002. Systematic analysis of K-feldspar 40Ar/39Ar step heating results II: Relevance of laboratory argon diffusion 
properties to nature. Geochimica et Cosmochimica Acta 66, 1237-1255.

Magni, V., Allen, M.B., van Hunen, J. and Bouilhol, P. 2017. Continental underplating after slab break-off, Earth and Planetary Science Letters, 474, 59 -67.

McDougall, I., Harrison, T.M., 1999. Geochronology and Thermochronology by the 40Ar/39Ar Method. Oxford University Press, Oxford, pp. 1-269.

McQuarrie, N., Barnes, J. B., and Ehlers, T. A. 2008. Geometric, kinematic, and erosional history of the central Andean Plateau, Boli vin $\left(1 \bar{J}-17^{\circ} \mathrm{S}\right)$, Tectonics, 27, TC3007, doi:10.1029/2006TC002054.

Meng, Q. R., and Zhang, G.W., 2000., Geologic f amı work and tectonic evolution of the Qinling orogen, central China. Tec ${ }^{\dagger}$ or Jnhysics, 323, 183-196.

Meng, Q.-R., Wang, E. and Hu, J.-M , 2 75. :Mesozoic sedimentary evolution of the northwest Sichuan basin: $\operatorname{In}_{n_{1}}$ lication for continued clockwise rotation of the South China block. Geolngi a' Society of America Bulletin, 117(3-4): 396-410.

Monié, P., Agard, P., 2009. Toeval blueschist exhumation along thousands of kilometers: Imr ‘. atıuns for subduction channel processes, Geochem. Geophys. Geosyst., 10, Q1 7002, doi:10.1029/2009GC002428.

Qiu, L., Yan, D.-P., Yang, W.-X., Wang, J., Tang, X. and Ariser, S., 2017. Early to Middle Triassic sedimentary records in the Youjiang Basin, South China: Implications for Indosinian orogenesis. Journal of Asian Earth Sciences, 141: 125-139.

Ratschbacher, L., Hacker, B.R., Webb, L.E., McWilliams, M., Ireland, T., Dong, S., Calvert, A., Chateigner, D., Wenk, H.R., 2000. Exhumation of the 
ultrahigh-pressure continental crust in east central China: Cretaceous and

Cenozoic unroofing and the Tan-Lu fault. Journal of Geophysical

Research-Solid Earth 105, 13303-13338.

Ratschbacher, L., Hacker, B.R., Calvert, A., Webb, L.E., Grimmer, J.C., McWilliams, M.O., Ireland, T., Dong, S.W., Hu, J.M., 2003. Tectonics of the Qinling (Central China): tectonostratigraphy, geochronology, and deformation history.

Tectonophysics 366, 1-53.

Reiners, P. W., Farley, K. A., \& Hickes, H. J. (2002). F e di fusion and (U-Th)/He thermochronometry of zircon: Initial result‘ fro 1 Fish Canyon Tuff and Gold Butte. Tectonophysics, 349, 297-308.

https://doi.org/10.1016/S0040-1 s (0<,00058-6

Reiners, P.W., 2005. Zircon (U-Thi ${ }^{1 / H e}$ thermochronometry. Low-Temperature Thermochronology: Technic 'lf s, Interpretations, and Applications 58, 151-179.

Reiners, P. W., Nicolescu, \& 2006. Measurement of parent nuclides for (U-Th)/He chronometry br wuinon sector ICP-MS. ARHDL Rep. 1 (http://www.gec arizona.edu/ reiners/arhdl/arhdl.htm).

Roger, F., Leloup, P.H., Jolivet, M., Lacassin, R., Trinh, P.T., Brunel, M., Seward, D., 2000. Long and complex thermal history of the Song Chay metamorphic dome (Northern Vietnam) by multi-system geochronology. Tectonophysics 321, $449-466$.

Roger, F., Jolivet, M., Malavieille, J., 2010. The tectonic evolution of the Songpan-Garze(North Tibet) and adjacent areas from Proterozoic to Present: A 
synthesis. J Asian Earth Sci 39, 254-269.

Scott, E., Allen, M.B., Macpherson, C.G., McCaffrey, K.J.W., Davidson, J.P., Saville, C., Ducea, M.N., 2018. Andean surface uplift constrained by radiogenic isotopes of arc lavas. Nature Communications 9, doi:10.1038/s41467-018-03173-4.

Shi, W., Wang, F., Yang, L., Wu, L., Zhang, W., 2018. Diachronous growth of the

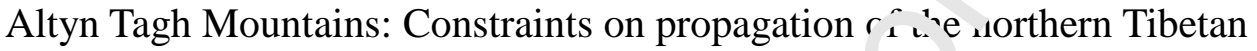
margin from (U-Th)/He dating. Journal of Geopl vsic al Research: Solid Earth, 123, 6000-6018. https://doi.org/10.1029/20 (7J`014844.

Shu, L.S., Zhou, X.M., Deng, P., Wang, B., Iad g, S.Y., Yu, J.H., Zhao, X.X., 2009. Mesozoic tectonic evolution of ne Sou heast China Block: New insights from basin analysis. J Asian Earti. Sci 34, 376-391.

Shu, L. S., Jahn, B. M., Charvet, J . ‘antosh, M., Wang, B., Xu, X. S., Jiang, S. Y., 2014. Intraplate tecto. n-magmatism in the Cathaysia Block (South China): Evidence from ${ }^{t} t_{\text {gr }}$ aphic, structural, geochemical and geochronological investigations. $f$ m. J. Sci. 314, 154-186.

Shu, L. S., Wang, B., Cawood, P. A., Santosh, M., Xu, Z. Q., 2015. Early Paleozoic and Early Mesozoic intraplate tectonic and magmatic events in the Cathaysia Block, South China. Tectonics 34, 1600-1621.

Strecker, M. R., R. N. Alonso, B. Bookhagen, B. Carrapa, G. E. Hilley, E. R. Sobel, and M. H. Trauth (2007), Tectonics and climate of the southern central Andes, Annual Review of Earth and Planetary Sciences 35, 747-787. 
Taghizadeh-Farahmand, F., Afsari, N., Sodoudi, F., 2015. Crustal thickness of Iran inferred from converted waves, Pure Appl. Geophys. 172, 309-331.

Tang, S.-L., Yan, D.-P., Qiu, L., Gao, J.-F. and Wang, C.-L., 2014. Partitioning of the Cretaceous Pan-Yangtze Basin in the central South China Block by exhumation of the Xuefeng Mountains during a transition from extensional to compressional tectonics? Gondwana Research, 25(4): 1644-1659.

Wan, Y., Liu, D., Wilde, S.A., Cao, J., Chen, B., Dong, C. Ñ ng, B., Du, L., 2010. Evolution of the Yunkai Terrane, South China: Ev. lenı e from SHRIMP zircon U-Pb dating, geochemistry and Nd isotope. I As1، n Earth Sci 37, 140-153.

Wang, C., Zhao, X., Liu, Z., Lippert, P.C., G as am, S.A., Coe, R.S., Yi, H., Zhu, L., Liu, S. and Li, Y., 2008. Constr..nı on the early uplift history of the Tibetan Plateau. Proceedings of the 'Tational Academy of Sciences, 105(13): 4987-4992. Wang, F., Wang, Q., Lin, W., Wu, .. Shi, W., Feng, H., Zhu, R., 2014. 40Ar/39Ar geochronology of the Vortn China and Yangtze Cratons: New constraints on Mesozoic cooli as anc cratonic destruction under East Asia. Journal of Geophysical Re earch: Solid Earth, doi: 10.1002/2013jb010708.

Wang, J.-G., Hu, X., Garzanti, E., Ji, W.-Q., Liu, Z.-C., Liu, X.-C., Wu, F.-Y., 2017. Early cretaceous topographic growth of the Lhasaplano, Tibetan plateau: Constraints from the Damxung conglomerate. Journal of Geophysical Research: Solid Earth 122, 5748-5765.Wang, W., Zhou, M.F., Yan, D.P., Li, L., John, M., 2013. Detrital zircon record of Neoproterozoic active-margin sedimentation in the eastern Jiangnan Orogen, South China. Precambrian Res. 235, 1-19. 
Wang, W., Zhou, M.-F., Zhao, J.-H., Pandit, M., Zheng, J.-P., Liu, Z.-R., 2016.

Neoproterozoic active continental margin in the southeastern Yangtze Block of

South China: evidence from the ca. 830-810 Ma sedimentary strata. Sediment.

Geol. 342, 254-267.

Wang, X.L., Zhou, J.C., Qiu, J.S., Zhang, W.L., Liu, X.M., Zhang, G.L., 2006.

LA-ICP-MS U-Pb zircon geochronology of the Neoproterozoic igneous rocks from Northern Guangxi, South China: implications fo. . stunic evolution.

Precambrian Res. 145, 111-130.

Wang, Y.J., Zhang, Y.H., Fan, W.M., Peng, T.P., 2 )05. Structural signatures and Ar-40/Ar-39 geochronology of the Indo in an Xuefengshan tectonic belt, South China Block. J Struct Geol 27, 9 9 נ-: 98.

Wang, Y.J., Fan, W.M., Cawood, I A., Ji, S.C., Peng, T.P., Chen, X.Y., 2007. Indosinian high-strain deform tti on for the Yunkaidashan tectonic belt, south China: Kinematics anc Ar-40/Ar-39 geochronological constraints. Tectonics 26.

Webb, L.E., Hacker, Г.. , a. atschbacher, L., McWilliams, M.O., Dong, S., 1999.

Thermochronolo ic constraints on deformation and cooling history of high- and ultrahigh-pressure rocks in the Qinling-Dabie orogen, eastern China. Tectonics 18, 621-638.

Wei, W., Chen, Y., Faure, M., Martelet, G., Lin, W., Wang, Q., Yan, Q., Hou, Q., 2016. An early extensional event of the South China Block during the Late Mesozoic recorded by the emplacement of the Late Jurassic syntectonic Hengshan Composite Granitic Massif (Hunan, SE China). Tectonophysics 672-673, 50-67. 
Wolf, R. A., Farley, K. A., Silver, L. T., 1996. Helium diffusion and low-temperature thermochronometry of apatite. Geochimica et Cosmochimica Acta, 60, 42314240. https://doi.org/10.1016/S0016-7037(96)00192-5.

Wu, L., Monié, P., Wang, F., Lin, W., Ji, W., Bonno, M., 2016. Cenozoic exhumation history of Sulu terrane: Implications from (U-Th)/He thermochronology. Tectonophysics, 672-673, 1-15. https://doi.org/10.1016/j.tecto.2016.01.035

Wu, F.-Y., Yang, J.-H., Xu, Y.-g., Wilde, S.A., Walker, R.J, ¿ר1乡. Destruction of the North China Craton in the Mesozoic. Annual Revi 2 w ( f Earth and Planetary Sciences, 47, 173-195.

Xu, G., Wang, E., 2010. The uplift mechanis o f Tongbai complex in Mesozoic and its coupling relationship with Na' ya Ig L asin. Chinese Journal of Geology, 45(3), 626-652 (in Chinese with Ens ${ }^{1}{ }^{\text {ish abstract). }}$

Xu, X.B., Zhang, Y.Q., Shu, L.S., iis, D., 2011. La-ICP-MS U-Pb and 40Ar/39Ar geochronology of the s. eared metamorphic rocks in the Wuyishan: Constraints on the timing of $\Gamma_{-m^{-1} y}$ ialeozoic and Early Mesozoic tectono-thermal events in SE China. Tecton shysics 501, 71-86.

Xue, Z., Martelet, G., Lin, W., Faure, M., Chen, Y., Wei, W., Li, S., Wang, Q., 2017. Mesozoic Crustal Thickening of the Longmenshan Belt (NE Tibet, China) by Imbrication of Basement Slices: Insights from Structural Analysis, Petrofabric and Magnetic Fabric Studies, and Gravity Modeling. Tectonics 36, 3110-3134.

Yan, D.P., Zhou, M.F., Song, H.L., Wang, X.W., Malpas, J., 2003. Origin and tectonic significance of a Mesozoic multi-layer over-thrust system within the Yangtze 
Block (South China). Tectonophysics 361, 239-254.

Yan, D.P., Zhou, M.F., Li, S.B., Wei, G.Q., 2011. Structural and geochronological constraints on the Mesozoic-Cenozoic tectonic evolution of the Longmen Shan thrust belt, eastern Tibetan Plateau. Tectonics 30, TC6005, doi:10.1029/2011TC002867.

Yang, D.-S., Li, X.-H., Li, W.-X., Liang, X.-Q., Long, W.-G., Xiong, X.-L., 2010. $\mathrm{U}-\mathrm{Pb}$ and 40Ar-39Ar geochronology of the Baiyunsh ..1 ¿ntiss (central Guangdong, south China): constraints on the timir of oarly Palaeozoic and Mesozoic tectonothermal events in the Wuyı ( ( 'uyi-Yunkai) Orogen. Geol Mag $147,481-496$.

Yin, A., and Nie, S., 1996, A Phanero o1 painspastic reconstruction of China and its neighboring regions, in The Tstonic Evolution of Asia edited by A. Yin and T.M. Harrison, Cambridge Univers tv Press, p. 442-485.

Yonkee, W.A., Weil, A.B., ¿n15. Tectonic evolution of the Sevier and Laramide belts within the North A ne ican Cordillera orogenic system. Earth-Science Reviews $150,531-593$.

Zhang, Q., Wang, Y.L., Jin, W.J., Li, C.D., 2008. Eastern China Plateau during the Late Mesozoic: evidence, problems and implication. Geological Bulletin of China, 27(9):1404-1430 (in Chinese with English abstract).

Zhang, J., Ma, Z.J., Yang, J., Chen, B.H., Lei, Y.L., Wang, Z.X., Li, T., 2010. The attributes of the Mesozoic basins along the western foothill of the Xuefengshan Mountains and its tectonic implications. Acta Geol Sin 84(5), 631-650 (in 
Chinese with English abstract).

Zheng, Y.F., Gong, B., Zhao, Z.F., Wu, Y.B., Chen, F.K., 2008. Zircon U-Pb age and O isotope evidence for Neoproterozoic low-O-18 magmatism during supercontinental rifting in South China: Implications for the snowball Earth event. Am J Sci 308, 484-516.

Zhong, D., 2000. Paleotethysides in West Yunnan and Sichuan, China.Science Press, Beijing, 248 p.

Zhou, X.M., Li, W.X., 2000. Origin of Late Mesozoic gne us rocks in Southeastern China: implications for lithosphere subductir $\mathrm{a}$ at 1 underplating of mafic magmas. Tectonophysics 326, 269-287.

Zhou, X.M., Sun, T., Shen, W.Z., Shv, L. J., , 'iu, Y.L., 2006. Petrogenesis of Mesozoic granitoids and volc nic rocks in South China: A response to tectonic evolution. Episodes 29, 26-3?

Zhu, G., Xie, C.-L., Chen, ' ', Xiang, B.-W., Hu, Z.-Q., 2010. Evolution of the Hongzhen metar. nhic core complex: Evidence for Early Cretaceous extension in the eastern Yar ştze craton, eastern China. Geol Soc Am Bull 122, 506-516.

Figure captions

Fig. 1. Tectonic map of the South China Block and its adjacent regions. CB: Cathaysia Block. ICB: Indochina Block. JSJ: Jinshajiang Suture zone. NCB: North China Block. SCB: South China Block. XFS: Xuefengshan. YB: Yangtze Block. DEM base map is generated from the software GeoMapApp (http://www.geomapapp.org). Metamorphic 
units of Triassic orogens are highlighted in pink.

Fig.2. Geological map of the Xuefengshan Belt (Modified after Chu et al., 2012a). BP:

Baimashan pluton. EZ: Eastern Zone. HS: Hengshan. MP: Miaoershan pluton. MXT:

Main Xuefengshan Thrust. WZ: Western Zone. YB: Yuanma Basin. YP: Yuechengling pluton. Sample localities of the north orogenic core and the south orogenic core are marked in Figs. 3a and 5a.

Fig. 3. (a) Geological map of the south orogenic ( ore 'SOC). Structural elements including foliation and lineation measureme' ts are based on this study and Chu et al. (2012b). (b) Cross-section showing tt e 1 ias ic décollement zone overprinted by Cretaceous extension. Note that $t_{1}$ - interface between the décollement zone and the weakly- or unmetamorphosed sed $m$ :ntary cover was inherited during the Cretaceous reworking.

Fig. 4. Field photos an d photomicrographs of structures observed in the south orogenic core. (a) Crenulated mylonitic foliation in the north of the décollement, location of sample XF295. (b) Folded mylonitic foliation of the décollement zone, location of sample XF300. (c) Quartz micaschist with pervasive crenulation, south of the décollement. (d) Crenulation folding the stretching lineation during the Triassic deformation, location of sample XF316B. (e) Superimposed $S_{c}$ crenulation in mica-rich layers, but Triassic mylonitic foliation $\left(\mathrm{S}_{1}\right)$ preserved in quartz-rich layers. 
Location at $500 \mathrm{~m}$ west of sample XF365. (f) Strongly crenulated micaschist $\left(\mathrm{S}_{\mathrm{c}}\right)$ superimposed of $S_{1}$ foliation. Note that the wavelength of crenulations is about 0.5-2 mm. Location at sample XF295. (g) Gently crenulated micaschist. Location at sample XF312. (h) Undeformed Miaoershan pluton. Note the points with incipient buldging recrystallization of large quartz grains. Location at sample XF270.

Fig. 5. (a) Geological map of the north orogenic core. Stru « raı elements including foliation and lineation measurements are based on this stua $y$ and Chu et al. (2012b). (b) Cross-section showing the Triassic décolleme it zc ne of the NOC.

Fig. 6. Geological map with sample 1 , ca i on $s$ and Ar-Ar and (U-Th)/He ages of samples in this study from the sou' $h$ orogenic core. Symbols for rock units are the same as those in Fig. 2a.

Fig. $7 .{ }^{40} \mathrm{Ar}-{ }^{39} \mathrm{Ar}$ mic ${ }^{\prime}{ }^{\prime}$ thug results in the study region. Age spectra are presented for (a) XF270, (b) XF30c (c) XF312, (d) XF313, (e) and (f) XF314, (g) XF316B, and (h) XF224. Sample locations are marked on Figs. 3 and 5. Bt: Biotite. Mus: Muscovite.

Fig. $8 .{ }^{40} \mathrm{Ar}-{ }^{39} \mathrm{Ar}$ mica dating results in the Chengbu region. Age spectra are presented for (a) XF295A, (b) and (c) XF365. Sample locations are marked on Fig. 3. Bt:

Biotite. Mus: Muscovite. 
Fig. 9. ${ }^{40} \mathrm{Ar}-{ }^{39} \mathrm{Ar} \mathrm{K}$-feldspar age spectra and the multi-domain diffusion modeling results of K-feldspar from (a) and (b): XF 270, and (c) and (d): XF349. Sample locations are marked on Figs. 3 and 5.

Fig. 10. Cooling paths of (a) the south orogenic core of the XFSB, and (b) the north orogenic core. In the south orogenic core, there were two episodes of fast cooling, whereas only the second episode is recorded in the north $r_{i} v_{i}^{r e n i c}$ core.

Fig. 11. Summary of available cooling paths relat :d th Cretaceous exhumation of Triassic orogens in East Asia. (a) Marginal $b$ ـll, around the SCB, including Dabieshan, Tongbaishan, and Sulu modified after L1 et . 1. (2015); Song Chay data are from Roger et al. (2000). (b) Intracontiı``ntal belts, including Baiyunshan (Yang et al., 2010), Yunkai Massif (Wang et al. 2 J07a; Chen et al., 2017), and Xuefengshan (this study). See Fig. 1 for locatı ns. Dashed parts of each cooling path represent a presumed thermal tra; + $^{+} \mathrm{O}_{1} \mathrm{y}$ of the belt.

Fig. 12. Tectonic models showing the evolution of the South China Block in the Triassic and Cretaceous within the Paleo-Pacific subduction system. (a) A broad intracontinental belt was created by flat-slab subduction ( $\mathrm{Li}$ and $\mathrm{Li}, 2007)$, producing an orogenic plateau that is similar to the present North American Cordillera, or Andes. The north orogenic core (NOC) of the Triassic belts experienced limited exhumation, whereas the south orogenic core (SOC) showed little effect. Continuous subduction in 
Jurassic maintained the plateau without further exhumation. (b) The two-stage Cretaceous extension exhumed the metamorphic orogenic cores of the Triassic belts, and finalized the current geological configuration of the South China Block. This phase of extension marked the collapse of the Mesozoic orogenic plateau in the South China Block.

Fig. 13. Area vs. time for comparison of present and ancie « laıaux in major subduction (light color) and collision (dark color) zonє s. $\mathrm{N}$ te that there is a change from subduction to collision for the Lhasaplano. Area is estimated by using Google Earth. Data for duration of plateaux are from. J. Wang et al. (2008), Law and Allen (2020); 2. Francois et al. (2014); 3. T' is tua ; 4. DeCelles (2004); 5. Kapp (2007), Wang et al. (2017); 6. McQuarrie ` + al. (2008), Scott et al. (2018).

Table 1. Summary of inforı ation from dated samples of the Xuefengshan Belt.

Weighted age refers $t=e^{\prime}$ nted plateau age for Ar-Ar dating, and weighted mean age for (U-Th)/He dating.

Appendix Table S1. Analytical Ar-Ar data of selected samples analyzed in Institute of Geology and Geophysics, Chinese Academy of Sciences.

Appendix Table S2. Analytical Ar-Ar data of selected samples analyzed in Geosciences Montpellier, University of Montpellier. 
Appendix Table S3. Analytical data on K-feldspar Ar-Ar dating of two granites.

Appendix Table S4. Analytical data on zircon (U-Th)/He dating from the south orogenic core.

Appendix Table S5. Analytical data on apatite (U-Th)/He ia:ng from the south orogenic core. 
A large plateau can be produced by crustal thickening in convergent zones such as continental collision belts and Andean-type subduction zones, but the life cycles of such plateaux are not well-understood. In particular, it is not clear how long they persist after construction, before other tectonic processes or erosion reduce crustal thickness and elevation to near-normal levels. Triassic subduction- and collision-tectonics produced intense deformation, magmatism and metamorphism across the entire South China Block. This large-scale crustal shortening created a broad orogenic belt, uplifted most parts of the So'.... Crina Block, and probably initiated the growth of an orogenic plateau. Our stud presents low-temperature thermochronology data from the Xuefengshan Belt in th e in ? rior of the South China Block. There was along-strike variation in exhumation. The $r$ or il orogenic core was subjected to Triassic ( 245-210 Ma), and Late Cretaceous ( 10r -8c Má, exhumation, whereas the cooling path of the south orogenic core reflects a two stace Cretaceous evolution. The variable exhumation pattern reflects non-uniform tectonics in $\mathrm{di}^{\prime}$ ' fe' ent regions, but both regions were subject to Late Cretaceous extension. We ten tively reconstruct the original plateau paleo-elevation to be $\sim 1.5$ $\mathrm{km}$ above sea level, br ${ }^{\prime} \iota_{1}$ the amount of exhumation $(\sim 10 \mathrm{~km})$ and the present crustal thickness ( $\sim 35 \mathrm{~km})$. The ${ }^{-}-\mathrm{t}$ trajectories of the Xuefengshan Belt and other Triassic belts highlight the significance of Cretaceous extension and exhumation in shaping the tectonic configuration of the South China Block. Large-scale extension was probably triggered by rollback of the Paleo-Pacific subduction zone. 
Yang Chu: Conceptualization, Methodology, Visualization, Writing - Original Draft, Writing Review \& Editing.

Wei Lin: Investigation, Supervision, Writing - Review \& Editing, Funding acquisition

Michel Faure: Investigation, Visualization, Writing - Review \& Editing

Mark B. Allen: Methodology, Visualization, Writing - Review \& Editing,

Zhentian Feng: Investigation 


\section{Declaration of interests}

$\bigotimes$ The authors declare that they have no known competing financial interests or personal relationships that could have appeared to influence the work reported in this paper.

$\square$ The authors declare the following financial interests/personal relationships which may be considered as potential competing interests: 
Highlights:

1. Thermochronology defines T-t cooling paths for the Xuefengshan Belt, South China

2. Orogenic cores of this Triassic belt were mainly exhumed to surface in Cretaceous

3. Episodic Cretaceous extension and exhumation finalized the tectonic configuration

4. A regional Mesozoic orogenic plateau was dissected by Cretaceous extension 


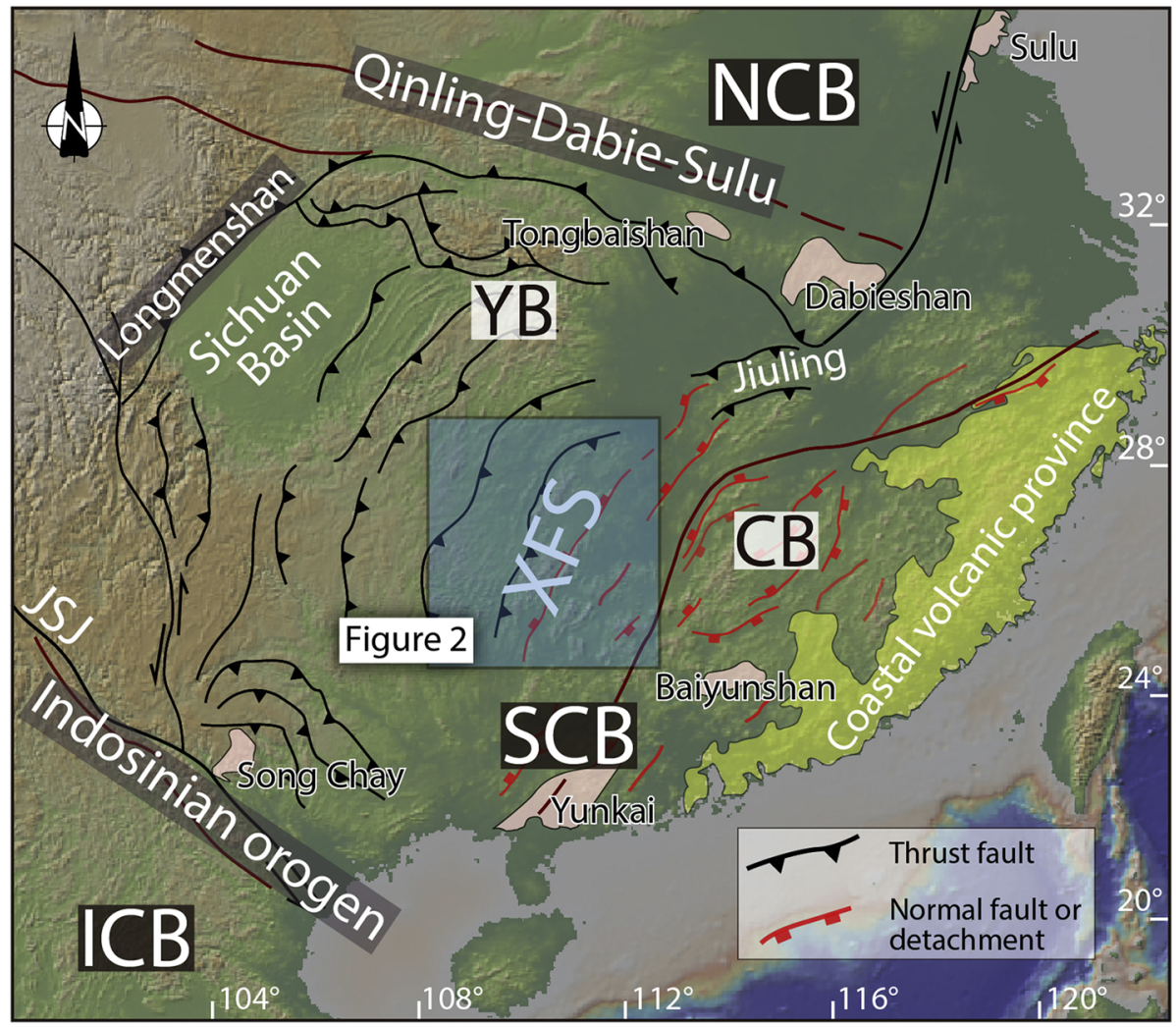

Figure 1 


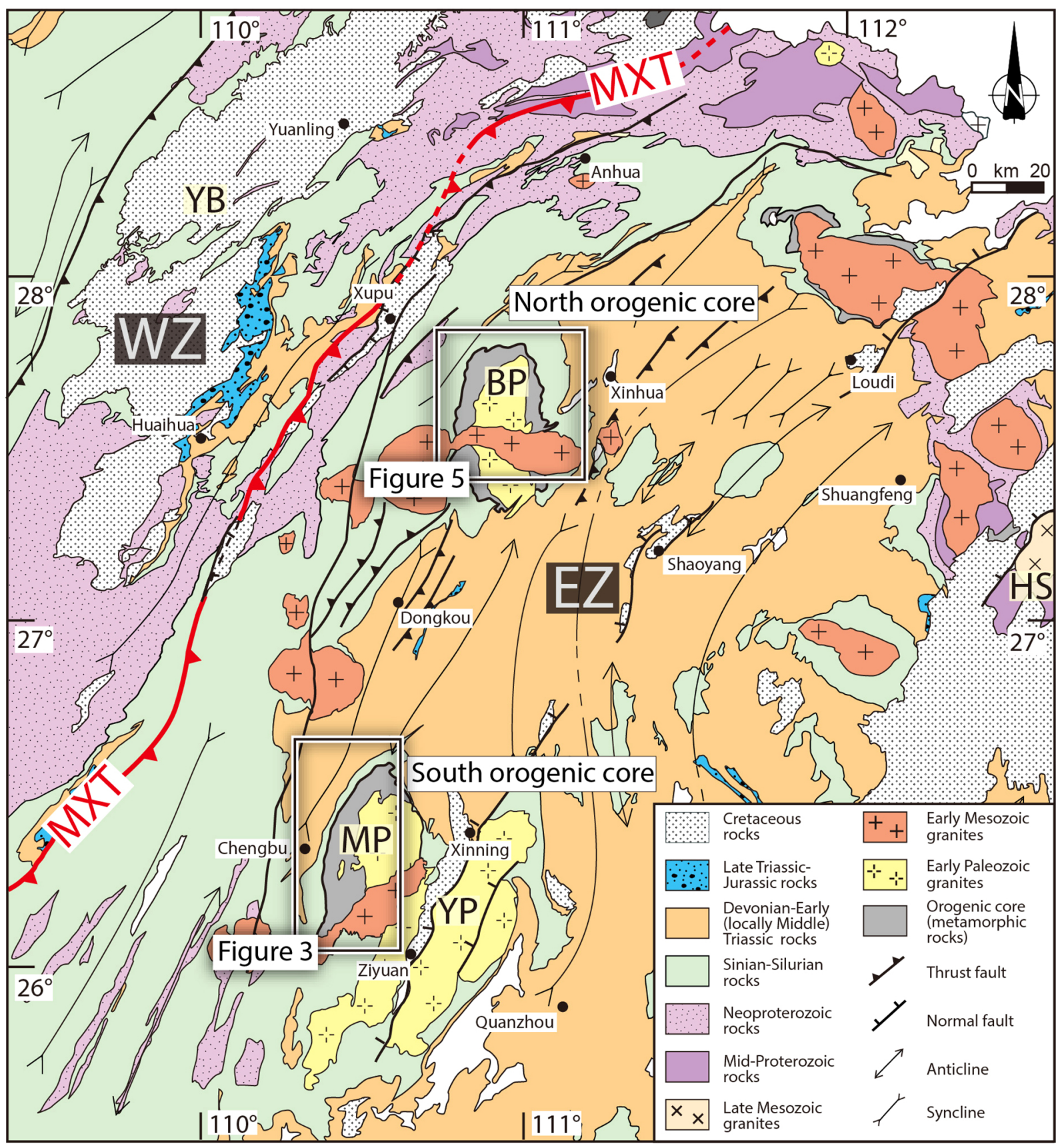




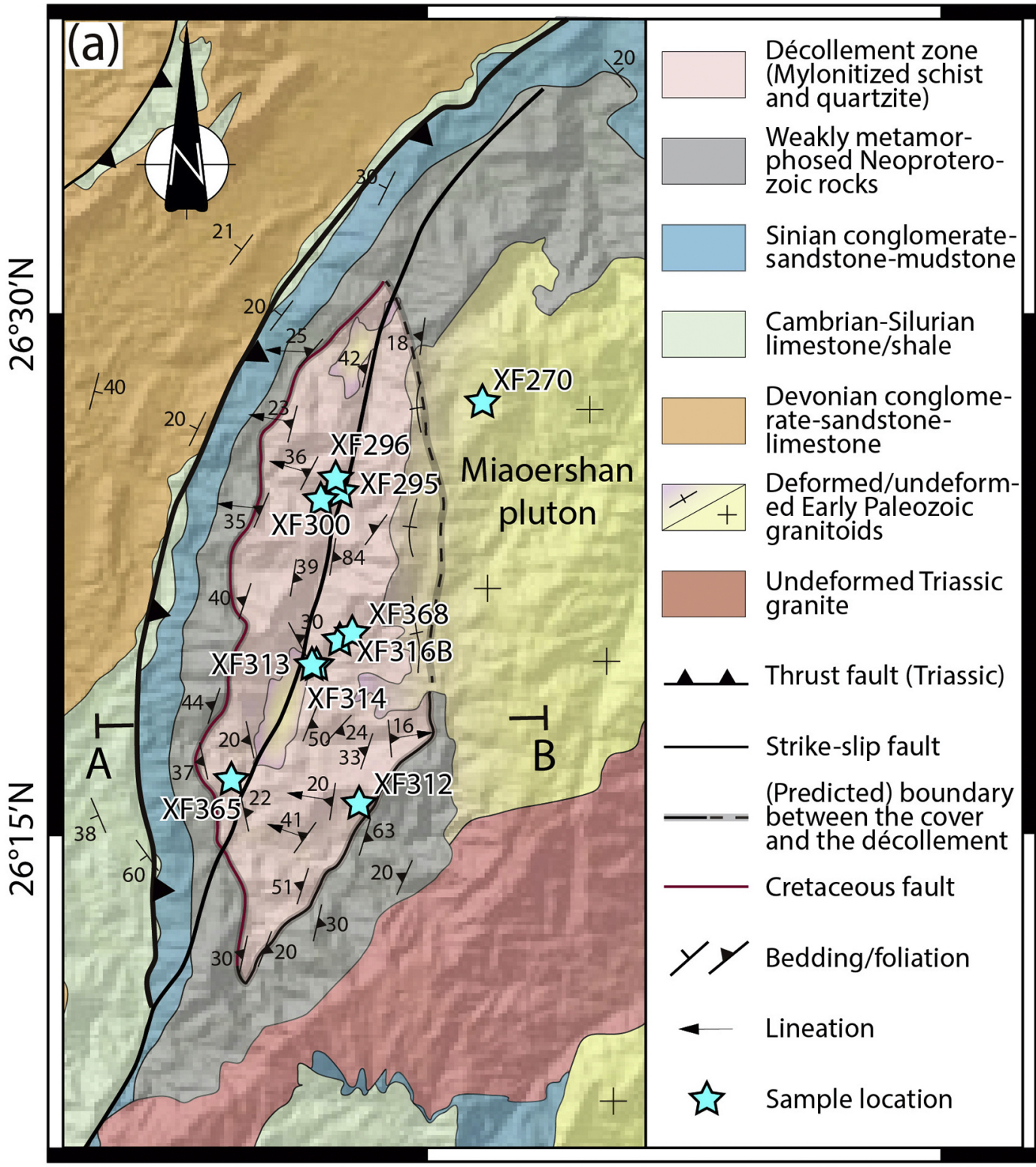

(b)

Cretaceous fault

1 Cretaceous extension

W

Triassic décollement

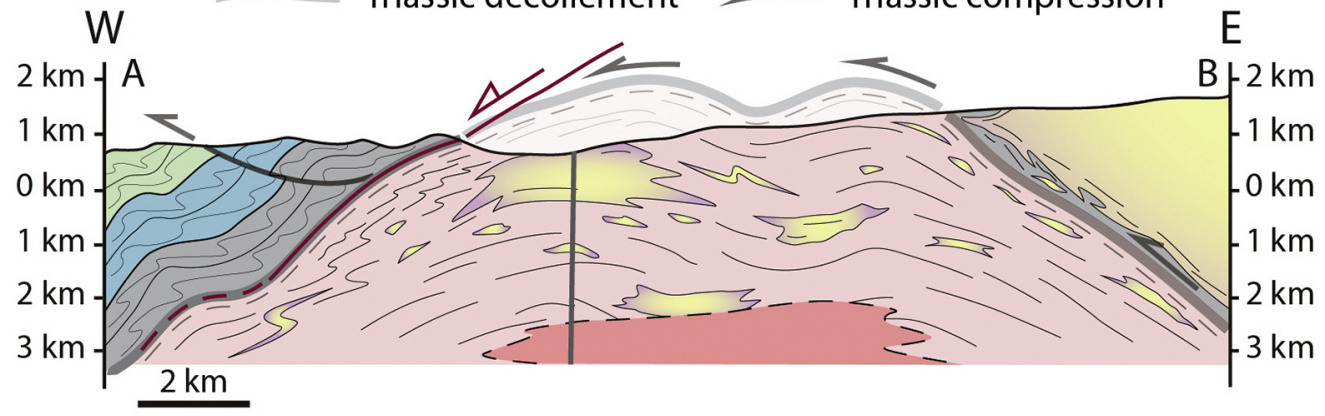



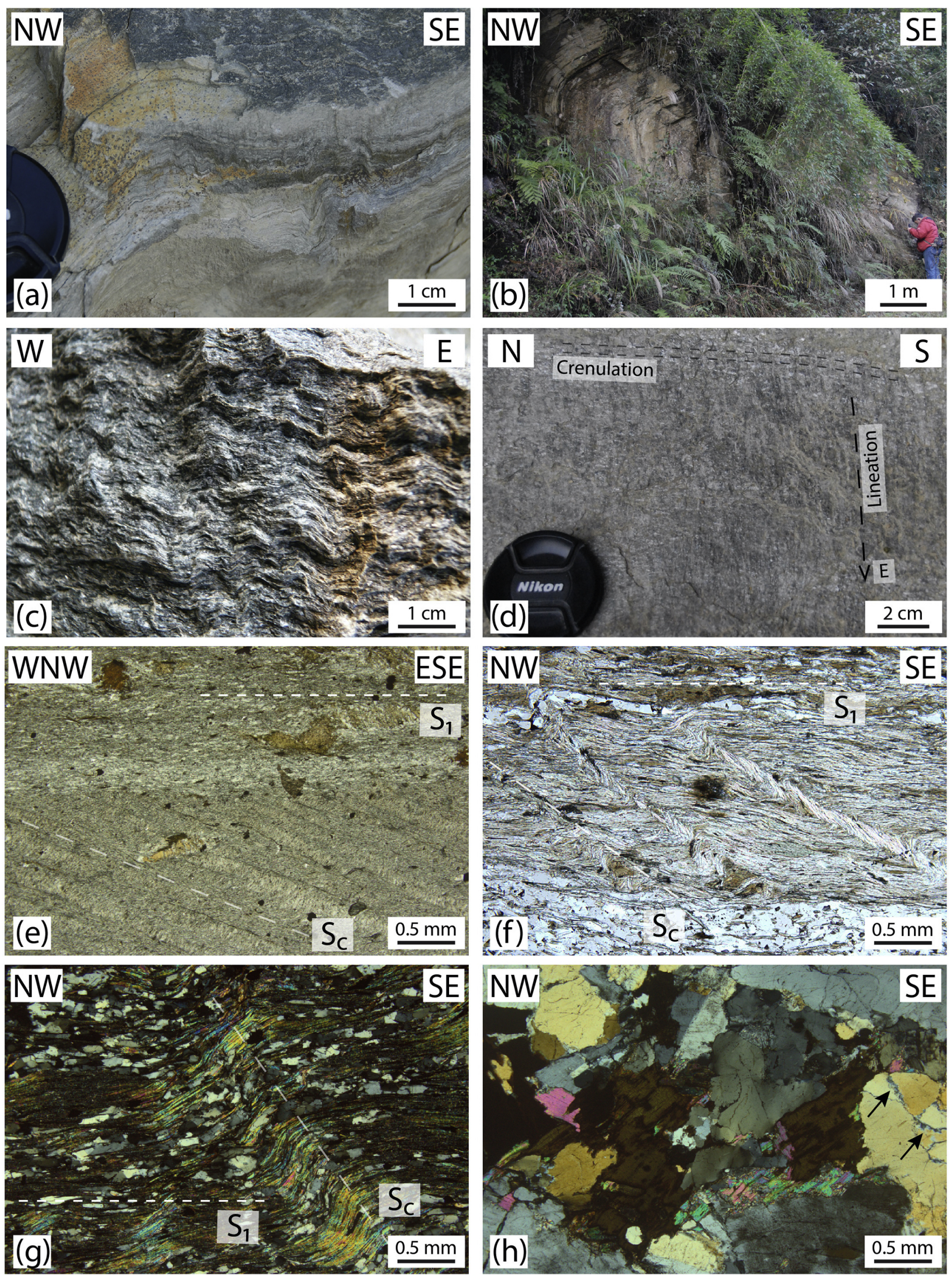


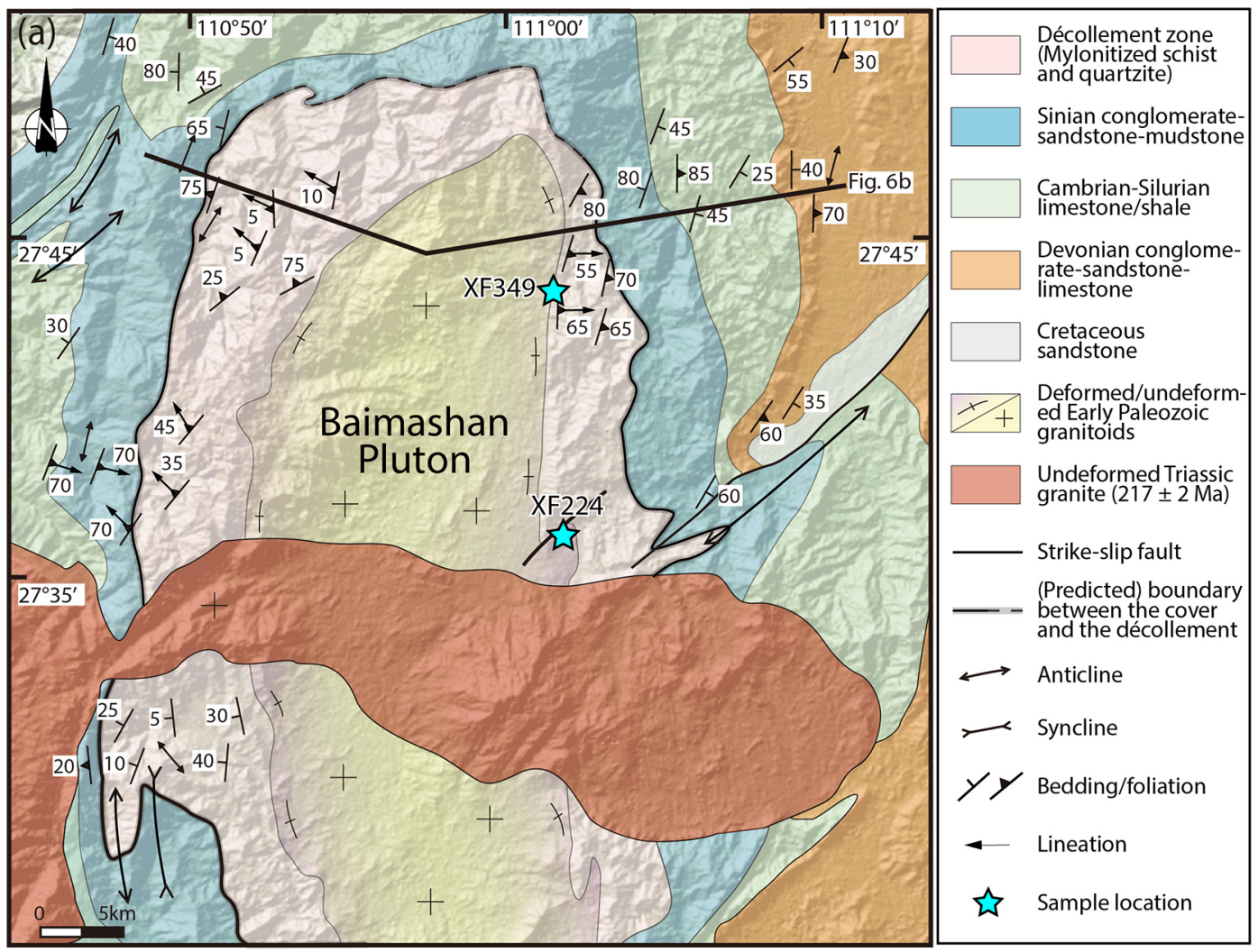

(b)

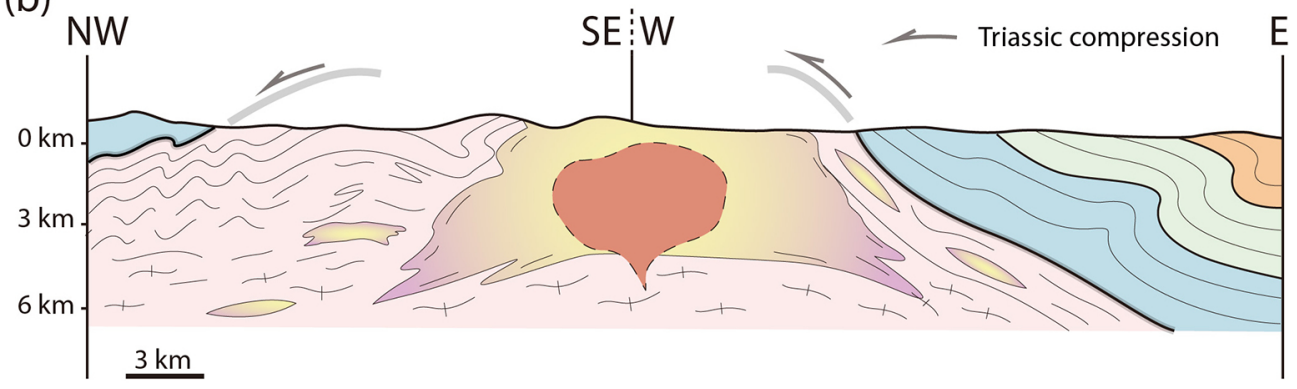

Figure 5 


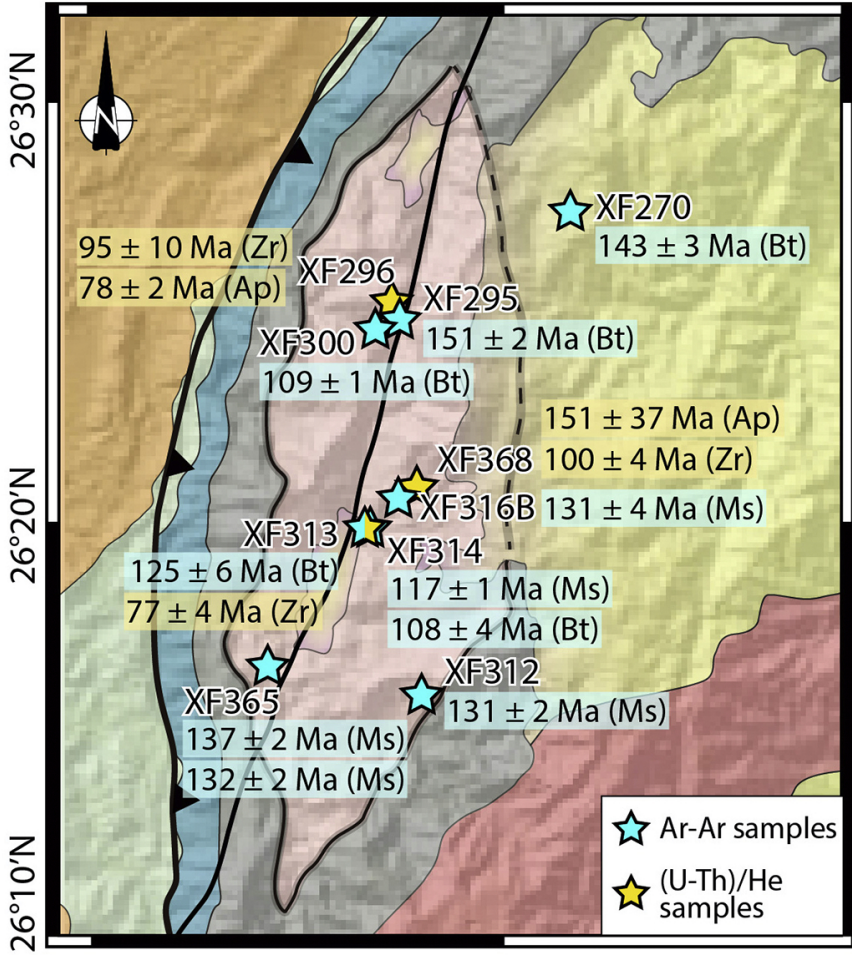

Figure 6 

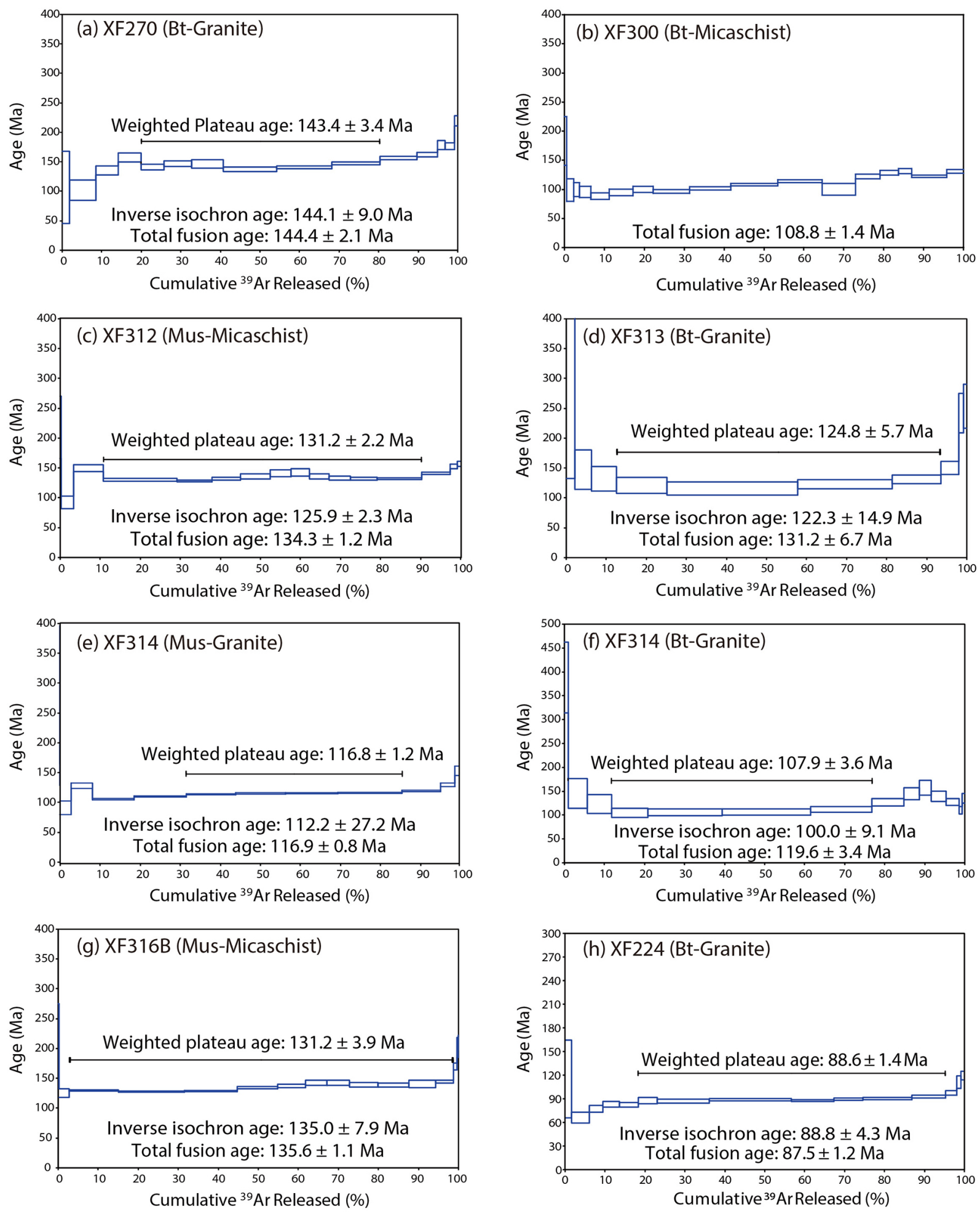

Figure 7 

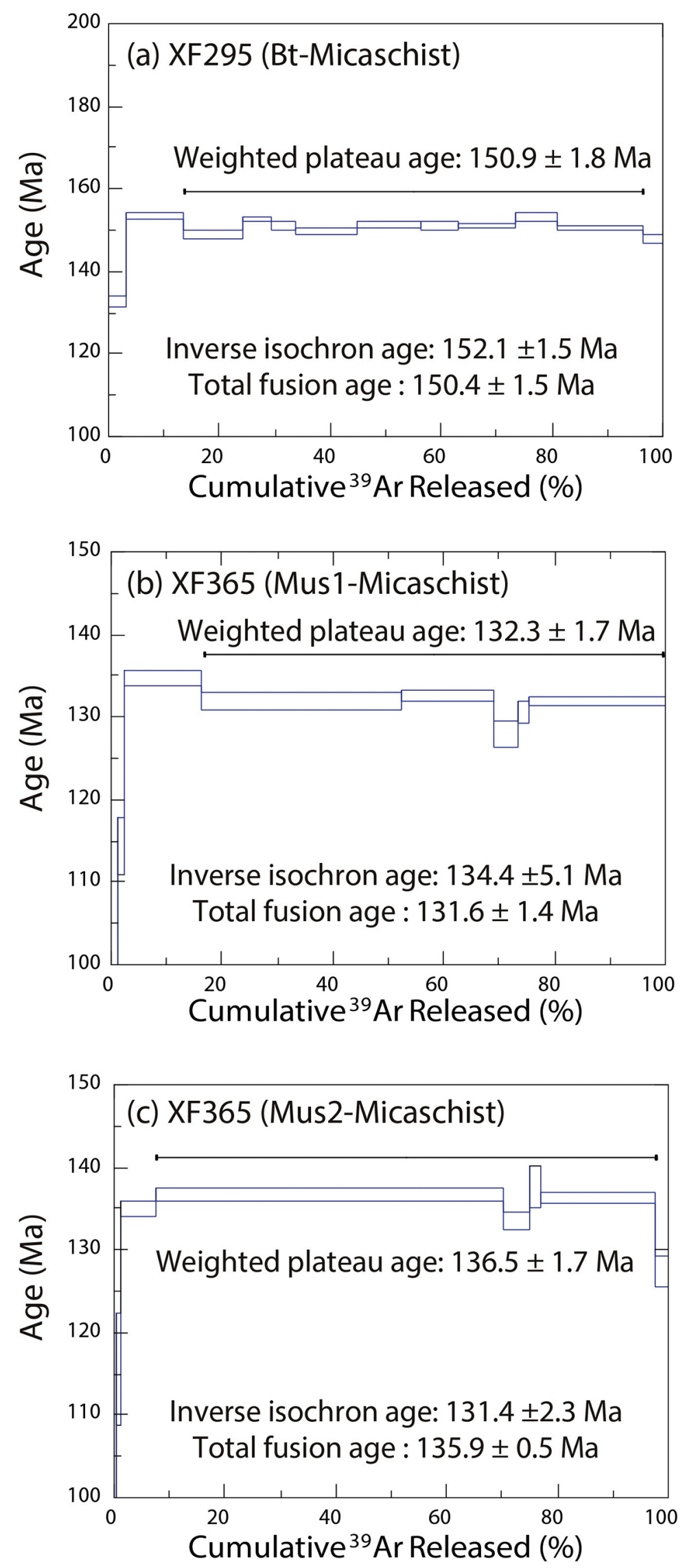

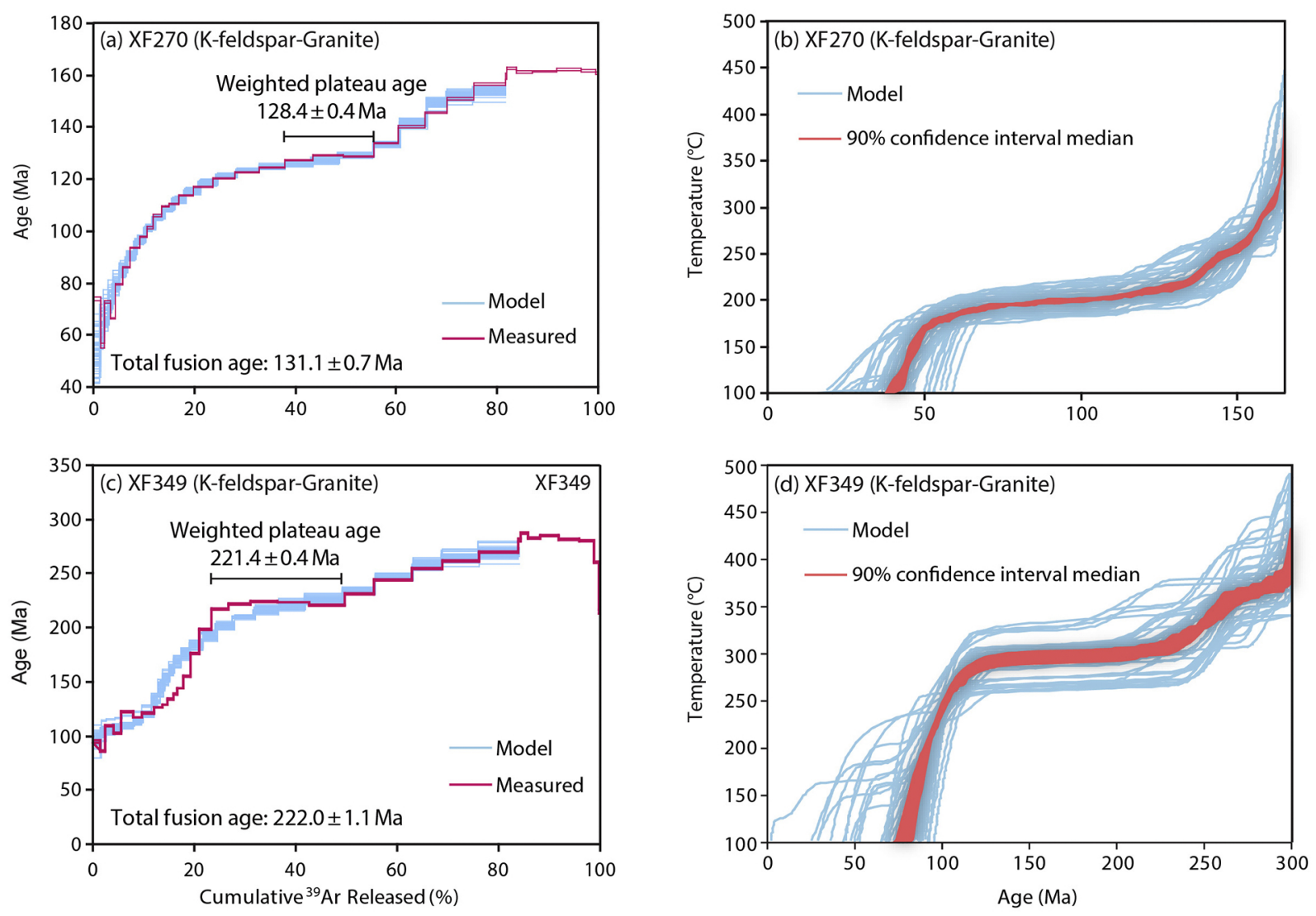

Figure 9 


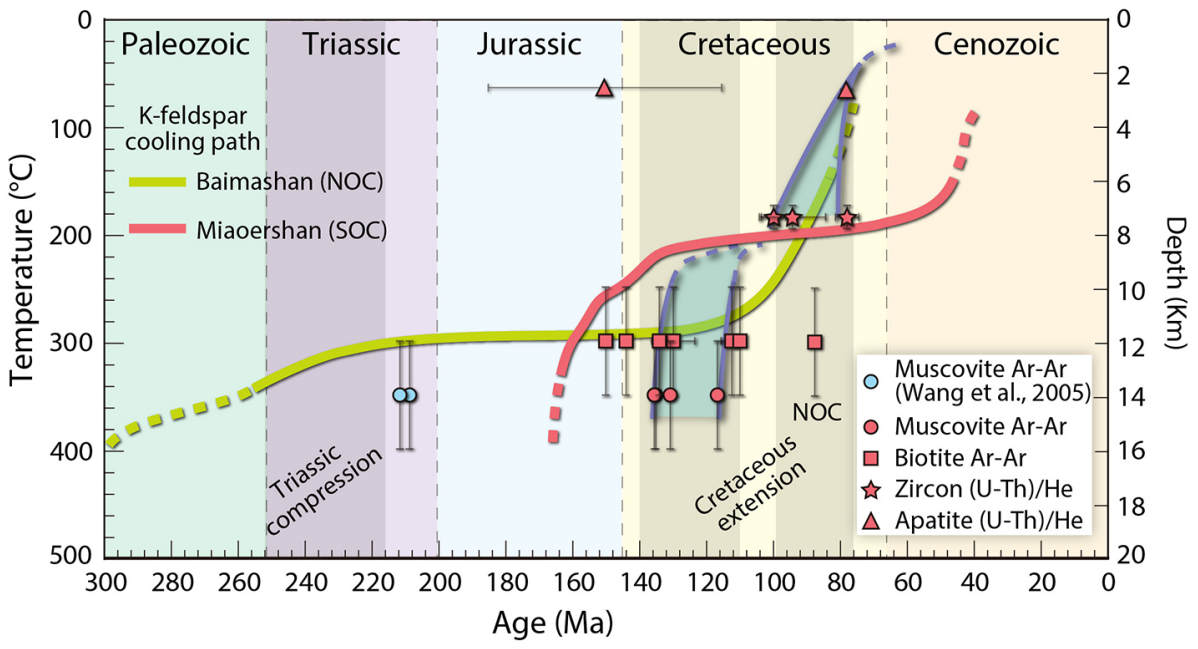

Figure 10 
(a) Marginal belts

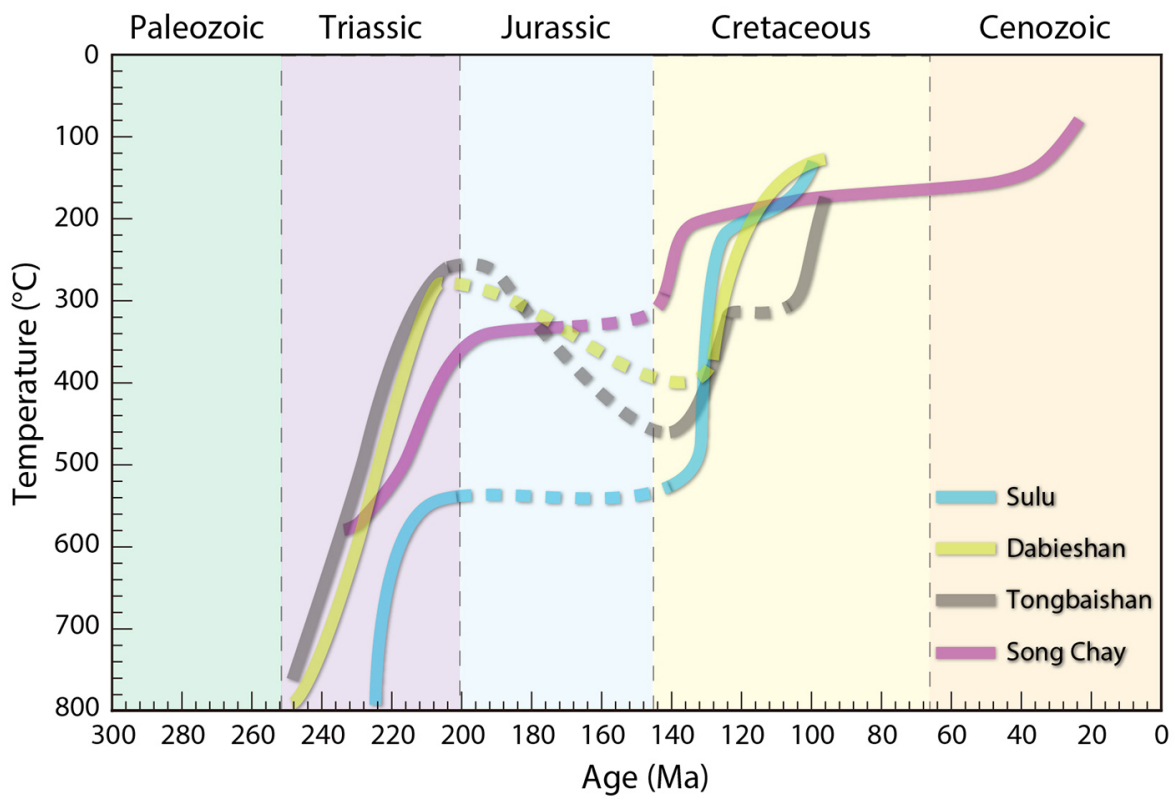

(b) Intracontinental belts

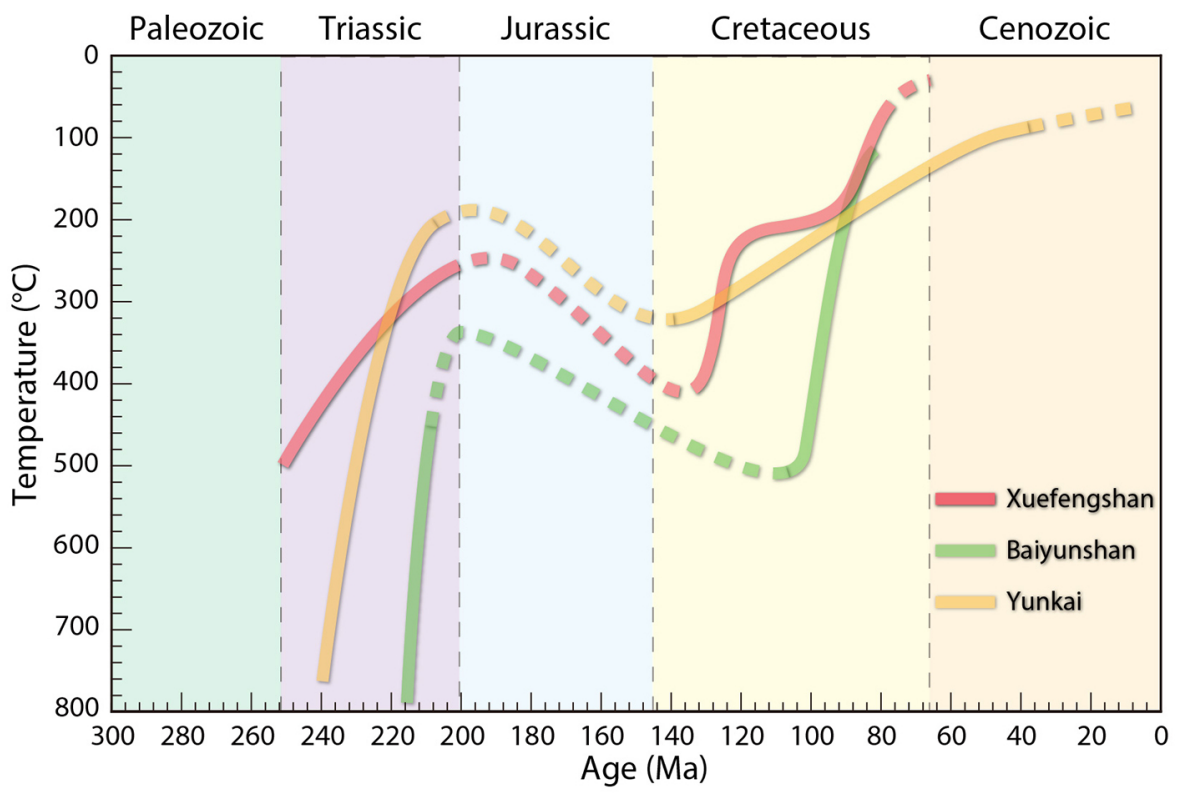


(a) Triassic: Flat subduction and formation of an orogenic plateau

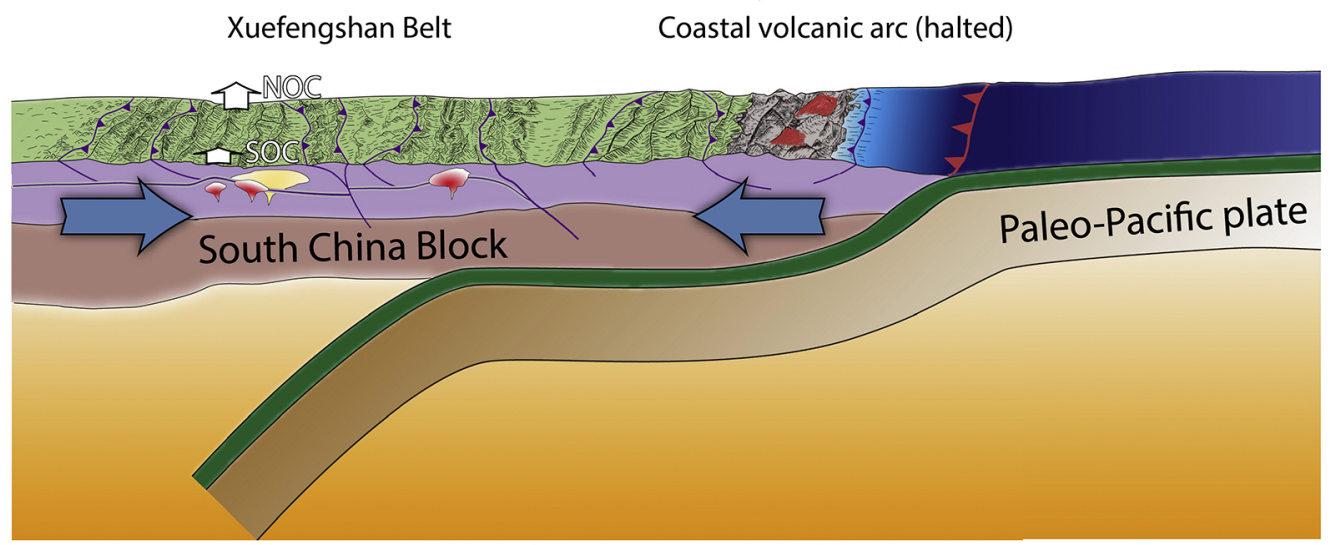

(b) Cretaceous: Back-arc extension and dissection of the plateau

Xuefengshan Belt

Coastal volcanic arc

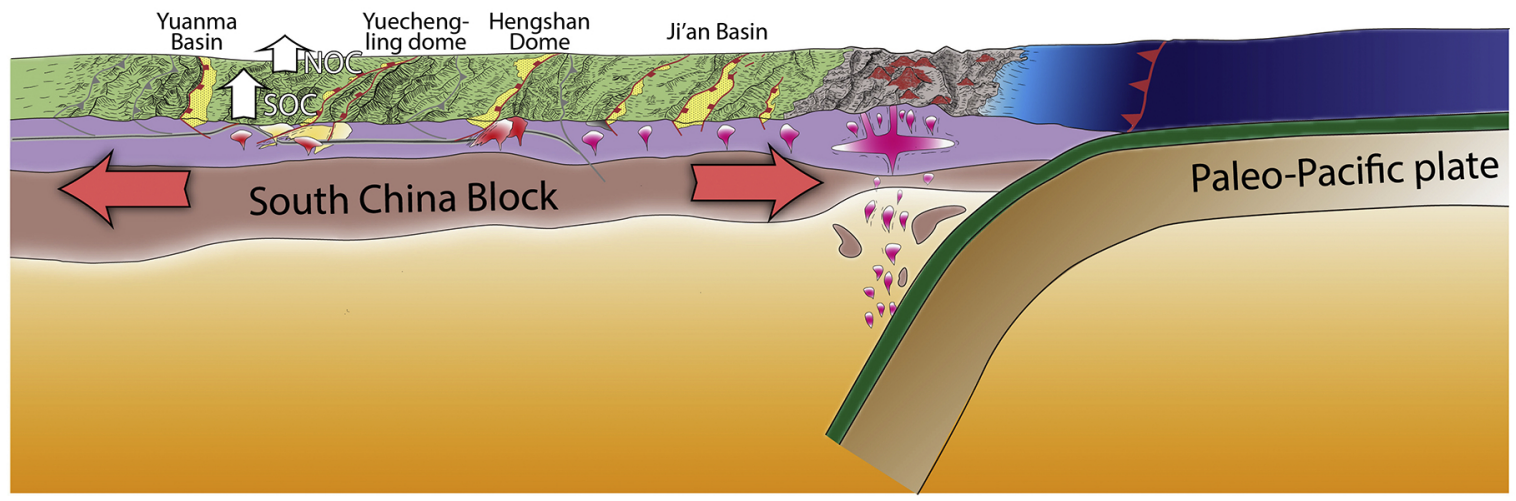


Area $\left(10^{4} \mathrm{~km}^{2}\right)$

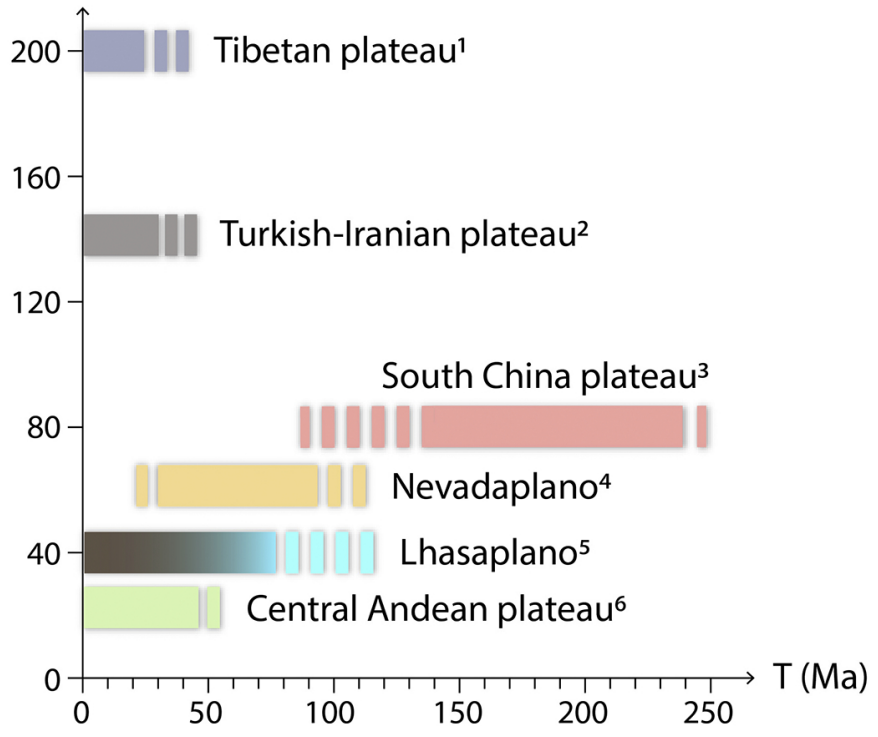

Figure 13 